\title{
Ammonia-oxidizing bacterial communities are affected by nitrogen fertilization and grass species in native $\mathrm{C}_{4}$ grassland soils
}

\author{
Jialin $\mathrm{Hu}^{1}{ }^{1}$, Jonathan D. Richwine ${ }^{2}$, Patrick D Keyser ${ }^{2}$, Lidong Li ${ }^{3}$, Fei Yao ${ }^{1}$, Sindhu Jagadamma ${ }^{1}$, Jennifer M \\ DeBruyn ${ }^{\text {Corresp. } 1}$ \\ 1 Department of Biosystems Engineering and Soil Science, University of Tennessee, Knoxville, Tennessee, United States \\ 2 Department of Forestry, Wildlife and Fisheries, University of Tennessee, Knoxville, Tennessee, United States \\ 3 Agroecosystem Management Research Unit, USDA-Agricultural Research Service, Lincoln, Nebraska, United States \\ Corresponding Author: Jennifer M DeBruyn \\ Email address: jdebruyn@utk.edu
}

Background. Fertilizer addition can contribute to nitrogen (N) losses from soil by affecting microbial populations responsible for nitrification. However, the effects of $\mathrm{N}$ fertilization on ammonia oxidizing bacteria under $\mathrm{C}_{4}$ perennial grasses in nutrient-poor grasslands are not well studied.

Methods. In this study, a field experiment was used to assess the effects of $\mathrm{N}$ fertilization rate $(0,67$, and $202 \mathrm{~kg} \mathrm{~N} \mathrm{ha}^{-1}$ ) and grass species (switchgrass [Panicum virgatum] and big bluestem [Andropogon gerardii]) on ammonia-oxidizing bacterial (AOB) communities in $\mathrm{C}_{4}$ grassland soils using quantitative PCR, quantitative reverse transcription-PCR, and high-throughput amplicon sequencing of amoA genes.

Results. Nitrosospira were dominant $\mathrm{AOB}$ in the $\mathrm{C}_{4}$ grassland soil throughout the growing season. $\mathrm{N}$ fertilization rate had a stronger influence on $A O B$ community composition than $\mathrm{C}_{4}$ grass species. Elevated $\mathrm{N}$ fertilizer application increased the abundance, activity, and alpha-diversity of $\mathrm{AOB}$ communities as well as nitrification potential, nitrous oxide $\left(\mathrm{N}_{2} \mathrm{O}\right)$ emission and soil acidity. The abundance and species richness of $A O B$ were higher under switchgrass compared to big bluestem. Soil $\mathrm{pH}$, nitrate, nitrification potential, and $\mathrm{N}_{2} \mathrm{O}$ emission were significantly related to the variability in AOB community structures $(p<$ 0.05). 
2 Ammonia-oxidizing bacterial communities are affected 3 by nitrogen fertilization and grass species in native $\mathrm{C}_{4}$ 4 grassland soils

Jialin $\mathrm{Hu}^{1}$, Jonathan D. Richwine ${ }^{2}$, Patrick D. Keyser ${ }^{2}$, Lidong $\mathrm{Li}^{3}$, Fei Yao ${ }^{1}$, Sindhu Jagadamma ${ }^{1}$, Jennifer M. DeBruyn ${ }^{1}$

${ }^{1}$ Department of Biosystems Engineering and Soil Science, University of Tennessee, Knoxville, Tennessee, United States

${ }^{2}$ Department of Forestry, Wildlife and Fisheries, University of Tennessee, Knoxville, Tennessee, United States

${ }^{3}$ USDA-Agricultural Research Service, Agroecosystem Management Research Unit, Lincoln, Nebraska, United States

Corresponding Author:

Jennifer M. DeBruyn ${ }^{1}$

2505 E J Chapman Drive, Knoxville, Tennessee, 37996, United States

Email address: jdebruyn@utk.edu

\section{Abstract}

Background. Fertilizer addition can contribute to nitrogen $(\mathrm{N})$ losses from soil by affecting microbial populations responsible for nitrification. However, the effects of $\mathrm{N}$ fertilization on ammonia oxidizing bacteria under $\mathrm{C}_{4}$ perennial grasses in nutrient-poor grasslands are not well studied.

Methods. In this study, a field experiment was used to assess the effects of $\mathrm{N}$ fertilization rate $(0$, 67 , and $202 \mathrm{~kg} \mathrm{~N} \mathrm{ha}^{-1}$ ) and grass species (switchgrass [Panicum virgatum] and big bluestem [Andropogon gerardii]) on ammonia-oxidizing bacterial (AOB) communities in $\mathrm{C}_{4}$ grassland soils using quantitative PCR, quantitative reverse transcription-PCR, and high-throughput amplicon sequencing of $a m o A$ genes.

Results. Nitrosospira were dominant $\mathrm{AOB}$ in the $\mathrm{C}_{4}$ grassland soil throughout the growing season. $\mathrm{N}$ fertilization rate had a stronger influence on $\mathrm{AOB}$ community composition than $\mathrm{C}_{4}$ grass species. Elevated $\mathrm{N}$ fertilizer application increased the abundance, activity, and alpha-diversity of $\mathrm{AOB}$ communities as well as nitrification potential, nitrous oxide $\left(\mathrm{N}_{2} \mathrm{O}\right)$ emission and soil acidity. The abundance and species richness of AOB were higher under switchgrass compared to big bluestem. Soil $\mathrm{pH}$, nitrate, nitrification potential, and $\mathrm{N}_{2} \mathrm{O}$ emission were significantly related to the variability in $\mathrm{AOB}$ community structures $(p<0.05)$. 
40

41

42

43

44

45

46

47

48

49

50

51

52

53

54

55

56

57

58

59

60

61

62

63

64

65

66

67

68

69

70

71

72

73

74

75

76

\section{Introduction}

Nitrifiers play an important role in the productivity and sustainability of agricultural ecosystems. Nitrification is the biological oxidation of ammonia $\left(\mathrm{NH}_{3}\right)$ to nitrate $\left(\mathrm{NO}_{3}^{-}\right)$, carried out in a twostep process by nitrifiers. Ammonia-oxidizers [ammonia-oxidizing bacteria (AOB), ammoniaoxidizing archaea (AOA), and comammox bacteria] control the first and rate limiting step of nitrification: oxidation of $\mathrm{NH}_{4}^{+}$to $\mathrm{NO}_{2}^{-}$(Daims et al., 2015; Frijlink et al., 1992; Venter et al., 2004). Nitrous oxide $\left(\mathrm{N}_{2} \mathrm{O}\right)$, a byproduct of ammonia oxidation (Bakken \& Frostegård, 2020; Hallin et al., 2018), is a greenhouse gas with a global warming potential 265-298 times that of $\mathrm{CO}_{2}$ and a major cause of the stratospheric ozone layer destruction (Qin et al., 2014; Ravishankara et al., 2009). About $56 \%-70 \%$ of the atmospheric $\mathrm{N}_{2} \mathrm{O}$ is contributed by microbial processes (such as nitrification and denitrification) in terrestrial ecosystems, with approximately $40 \%$ of terrestrial $\mathrm{N}_{2} \mathrm{O}$ emissions derived from agricultural soils (Conrad, 1996; Davidson, 2009; Syakila \& Kroeze, 2011). In many cropping systems nitrification is the main source of $\mathrm{N}_{2} \mathrm{O}$ emissions from soils (Liu et al., 2016). $\mathrm{N}_{2} \mathrm{O}$ emissions from $\mathrm{AOB}$ activity is higher than from comammox bacteria and AOA because these later two groups lack homologues of AOB NO reductase (Prosser et al., 2020). In agricultural soils with $\mathrm{N}$ fertilization, nitrification can also lead to nitrate $\left(\mathrm{NO}_{3}{ }^{-}\right)$leaching (Beeckman et al., 2018), potentially contributing to eutrophication of nearby water systems (Cameron et al., 2013). Major perennial forage crops prefer to take up $\mathrm{N}$ in the form of $\mathrm{NO}_{3}{ }^{-}$rather than $\mathrm{NH}_{4}^{+}$(Xu et al., 2019), thus nitrifiers play a role in forage productivity.

AOB convert $\mathrm{NH}_{3}$ to $\mathrm{NO}_{2}^{-}$through two enzymes: ammonia monooxygenase (AMO) and hydroxylamine oxidoreductase (HAO) (Araki et al., 2004; Prosser et al., 1986) whereas AOA lack HAO homologs and may oxidize ammonia via nitroxyl (HNO) (Levy-Booth et al., 2014; Schleper \& Nicol, 2010; Walker et al., 2010). Molecular ecology studies of AOA and AOB populations often use the marker gene amoA, which encodes $\alpha$-subunit of AMO containing the active site (Kowalchuk et al., 2000; Levy-Booth et al., 2014; Purkhold et al., 2000; Rotthauwe et al., 1997). Although AOA appear to be more numerically abundant than AOB in some soils (Leininger et al., 2006), the abundance and community composition of $\mathrm{AOB}$ are more responsive to $\mathrm{N}$ fertilization, and therefore are functionally dominant for $\mathrm{NH}_{3}$ oxidation in fertilized agricultural soils (Di et al., 2009; Jia \& Conrad, 2009; Ouyang et al., 2016; Segal et al., 2017; Ying et al., 2017). The functional dominance of AOBs suggests this group should be the focus when developing strategies to control nitrification in agricultural soils. Many studies have demonstrated that the majority of known AOB in soil are Nitrosospira spp., with lesser contributions from Nitrosococcus and Nitrosomonas (Lourenco et al., 2018; Pommerening-Roser \& Koops, 2005; Stephen et al., 1996).

Grasslands account for about $46.8 \%$ of all agricultural lands in the United States (USDA-NASS, 2012). Grasslands mobilize large pools of $\mathrm{N}$ with potential for $\mathrm{N}$ losses through $\mathrm{N}_{2} \mathrm{O}$ emissions and $\mathrm{NO}_{3}{ }^{-}$leaching (Di \& Cameron, 2002; Duan et al., 2017; Francis et al., 1995; Hansen et al., 2007) with nitrification as a key control. Some grass species produce root exudates containing 
77 compounds that inhibit the enzymes $\mathrm{AMO}$ and $\mathrm{HAO}$, known as biological nitrification inhibition 78 (BNI) (Subbarao et al., 2009). BNI varies significantly among different grass species. A previous 79 study has shown that $\mathrm{C}_{4}$ grasses (e.g. Brachiaria and Sorghum) exhibit greater BNI than $\mathrm{C}_{3}$ grasses 80 (e.g. ryegrass and fescue) (Subbarao et al., 2006). Perennial native $\mathrm{C}_{4}$ grasses, such as switchgrass 81 (Panicum virgatum $[\mathrm{SG}]$ ) and big bluestem (Andropogon gerardii $[\mathrm{BB}]$ ), have been widely planted 82 due to their drought-tolerance and high productivity under N-poor conditions (Fike et al., 2006; 83 Parrish \& Fike, 2005). A previous study reported that the optimum $\mathrm{N}$ rate for switchgrass to 84 maximize dry matter yield (50 to $120 \mathrm{~kg} \mathrm{~N} \mathrm{ha}^{-1}$ ) was higher than that for big bluestem (45 to 90 $85 \mathrm{~kg} \mathrm{~N} \mathrm{ha}^{-1}$ ) (Brejda, 2000), which may be due to the difference in BNI between these two $\mathrm{C}_{4}$ grass 86 species and/or the greater N-use efficiency of big bluestem than switchgrass (Friesen \& Cattani, 87 2017). Further, switchgrass contains a higher crude protein content compared to big bluestem 88 (Newell, 1968) suggesting that switchgrass may provide more available $\mathrm{N}$ for AOB via plant 89 90

91 92 93 residue decomposition. However, the $\mathrm{AOB}$ communities associated with these two $\mathrm{C}_{4}$ grass species have not been well documented.

Studies have found that $\mathrm{AOB}$ abundances and activity increase with $\mathrm{NH}_{4}{ }^{+}$addition, and correlate to nitrification rates (Di et al., 2009; Smits et al., 2010; Wertz et al., 2012), and that AOB community structure can be altered by $\mathrm{N}$ addition (Avrahami et al., 2003; Rooney et al., 2010; Wertz et al., 2012) and plant species (Faulwetter et al., 2013; Rooney et al., 2010) in other soils. However, there is a lack of understanding of the impact of $\mathrm{N}$ addition on AOB populations in native $\mathrm{C}_{4}$ grasslands. To address this, our study aimed to: (i) determine the effects of $\mathrm{N}$ fertilization rate and grass species on $\mathrm{AOB}$ communities; and (ii) identify edaphic properties that related to AOB abundance, activity, richness, evenness, and community composition, with a particular focus on the relationship of $\mathrm{AOB}$ with soil nitrification potential and $\mathrm{N}_{2} \mathrm{O}$ emissions. We hypothesized that: 1) $\mathrm{N}$ fertilization would promote $\mathrm{AOB}$ abundance, activity, richness and evenness, as well as nitrification potential and $\mathrm{N}_{2} \mathrm{O}$ emission; and a high $\mathrm{N}$ fertilization rate would alter AOB community structure; and 2) the abundance, activity, richness, and evenness of AOB would be higher under switchgrass than big bluestem because of differences in protein content and/or BNI between the grass species. This study was conducted in a native grassland plot experiment, and quantitative PCR (qPCR) of amoA genes from extracted DNA was used to estimate AOB abundances, quantitative reverse transcription PCR (qRT-PCR) of $a m o A$ genes from extracted RNA was used to estimate $\mathrm{AOB}$ activity, and high-throughput amplicon sequencing of $\mathrm{AOB}$ amo $\mathrm{A}$ genes was used to examine $\mathrm{AOB}$ alpha-diversity and community composition. AOB population data was then correlated to a suite of soil physicochemical properties, $\mathrm{N}_{2} \mathrm{O}$ emissions, and nitrification potentials.

\section{Materials \& Methods}

\section{Experimental design and sample collection}

This study was conducted at a small-plot trial at the University of Tennessee East Tennessee 
115 Research and Education Center (ETREC) in Knoxville, TN $\left(35.53^{\circ} \mathrm{N}, 83.06^{\circ} \mathrm{W}\right)$. Soils at this site 116 are classified as sandy loam (fine-loamy, mixed, semiactive, thermic Typic Hapludults) with $11759.9 \%$ sand, 23.5\% silt, and 16.6\% clay (Bandopadhyay et al., 2020). The experimental design 118 was a randomized complete block with split-plot treatment arrangements. The main plots had two $119 \mathrm{C}_{4}$ native grass species [switchgrass (SG) (Panicum virgatum) and big bluestem (BB) 120 (Andropogon gerardii)] and the split-plots had different urea fertilization rates [0, 67, and $202 \mathrm{~kg}$ $121 \mathrm{~N} \mathrm{ha}^{-1}(0 \mathrm{~N}, 67 \mathrm{~N}$, and $202 \mathrm{~N}$, respectively)]. Each combination of grass species and $\mathrm{N}$ rate had three 122 replications. Grasses were planted in 2013, treatments were applied in 2014. Full experimental 123 details, including the application of other fertilizers, lime, and herbicides were described in detail 124 in our previous study (Hu et al., 2021b).

125 After five years of the experimental treatments, soil samples were collected as previously 126 described (Hu et al., 2021b). Briefly, samples were collected at three grass growing seasons in

127

128

129

130

131

132

133

134

135

136

137

138

139

140

141

142

143

144

145

146

147

148

149

150

151 2019: grass green up (G, late April, one week before the first $\mathrm{N}$ fertilization), initial grass harvest ( $\mathrm{H} 1$, late June, within one week after harvest and before the second $\mathrm{N}$ fertilization), and second grass harvest (H2, Mid-August, within one week before harvest). Six soil cores (2.5 cm diameter, $10 \mathrm{~cm}$ long) were collected from each sub-plot and composited. A $10 \mathrm{~g}$ sub-sample was immediately stored at $-80^{\circ} \mathrm{C}$ for DNA and RNA extraction, and the remainder of the soil sample was used for soil physicochemical properties and nitrification potential measurements.

\section{Soil physicochemical analysis and nitrification potential}

Soil $\mathrm{pH}$, soil water content ( $\mathrm{SWC}$ ), $\mathrm{NH}_{4}{ }^{+}-\mathrm{N}, \mathrm{NO}_{3}{ }^{-} \mathrm{N}$, and nitrification potential were analyzed using freshly collected soil. Total organic carbon (TOC), total nitrogen (TN), dissolved organic carbon (DOC), and dissolved organic nitrogen (DON) were analyzed using air-dried soils using established methods described in our previous study (Hu et al., 2021b). Soil nitrification potential was measured using a chlorate block method (Belser \& Mays, 1980). Briefly, soil samples (2 g) were mixed with $14 \mathrm{~mL}$ nitrification potential medium $\left(4 \mathrm{~mL} 0.2 \mathrm{M} \mathrm{K}_{2} \mathrm{HPO}_{4}, 0.5 \mathrm{~mL} 0.2 \mathrm{M}\right.$ $\mathrm{KH}_{2} \mathrm{PO}_{4}, 2.5 \mathrm{~mL} 0.2 \mathrm{M}\left(\mathrm{NH}_{4}\right)_{2} \mathrm{SO}_{4}$ and $10 \mathrm{~mL} 1 \mathrm{M} \mathrm{NaClO}_{3}$ in $983 \mathrm{~mL}$ deionized water) in $50 \mathrm{ml}$ tubes and shaken for 4-6 hours $\left(175 \mathrm{rpm}, 25^{\circ} \mathrm{C}\right)$. The nitrification potential medium is a solution containing adequate $\mathrm{NH}_{4}{ }^{+}$and $\mathrm{PO}_{4}{ }^{3-}$ to maximize nitrification rates along with chlorate to block nitrite oxidation to nitrate. $1 \mathrm{~mL}$ slurry subsamples were removed at $3 \mathrm{~h}$ intervals and centrifuged to remove soil particles. $\mathrm{NO}_{2}^{-}$concentrations were determined by adding $50 \mu \mathrm{L}$ of $\mathrm{NO}_{2}{ }^{-}$color reagent ( $4 \mathrm{~g}$ of sulfanilamide and $0.1 \mathrm{~g} \mathrm{~N}$-(1-naphthyl)-ethylenediamine hydrochloride and $17 \mathrm{~mL}$ $85 \%$ phosphoric acid in $87.6 \mathrm{~mL}$ deionized water) to $200 \mu \mathrm{L}$ of centrifuged samples in a 96 -well plate. After $15 \mathrm{~min}$, the absorbance was measured in a microplate reader spectrophotometrically at $\lambda=543 \mathrm{~nm}$. We used absorbance values for the $\mathrm{NO}_{2}^{-}$standards to compute the $\mathrm{NO}_{2}{ }^{-}$ concentration for each sample, subtracting the non-soil controls. Nitrification potential was calculated as $\mu \mathrm{g} \mathrm{NO}_{2}^{-}-\mathrm{N} \mathrm{g}^{-1}$ dry weight soil hour ${ }^{-1}\left(\mathrm{gdw}^{-1} \mathrm{~h}^{-1}\right)$.

\section{Soil $\mathrm{N}_{2} \mathrm{O}$ emissions}


152 Soil $\mathrm{N}_{2} \mathrm{O}$ emissions were measured using the static chamber method (Collier et al., 2014) on the

153

154

155

156

157

158

159

160

161

162

163

164

165

166

167

168

169

170

171

172

173

174

175

176

177

178

179

180

181

182

183

184

185

186 same days that soil samples were taken. A circular stainless-steel base $(15 \mathrm{~cm}$ in diameter, $16 \mathrm{~cm}$ in height) was inserted into the soil to a depth of approximately $8 \mathrm{~cm}$ at the center of each subplot. The chamber was closed with a lid and gases were sampled through a valve in the lid with plastic syringes $(30 \mathrm{~mL})$ at four-time intervals $(0,20,40$, and $60 \mathrm{~min})$. The samples were transferred to pre-evacuated glass vials $(12 \mathrm{~mL})$. Soil temperature was measured by inserting a digital thermometer (Thermo Scientific, USA) one inch into the soil adjacent to the chamber.

Gas samples were analyzed in a gas chromatograph (Shimadzu GC-2014, Japan) with an electron capture detector for $\mathrm{N}_{2} \mathrm{O}$ determination. $\mathrm{N}_{2} \mathrm{O}$ flux was calculated by linear interpolation of the four sampling times. The $\mathrm{N}_{2} \mathrm{O}-\mathrm{N}$ emission flux was calculated as follows:

$$
F=\rho \times h \times \mathrm{d} c / \mathrm{d} t \times 273 /(273+T) \times k
$$

Where $F$ is emission flux $\left(\mu \mathrm{g} \mathrm{N} \mathrm{m}^{-2} \mathrm{~h}^{-1}\right) ; \rho$ is the $\mathrm{N}_{2} \mathrm{O}-\mathrm{N}$ density in standard state $\left(1.25 \mathrm{~kg} \mathrm{~m}^{-3}\right) ; h$ is the net height of static chamber $(0.08 \mathrm{~m}) ; \mathrm{d} c / \mathrm{d} t$ is the rate of gas concentration change $\left(\mu \mathrm{L} \mathrm{L}^{-1}\right.$ $\left.\min ^{-1}\right) ; T$ is the average soil temperature in the static chamber during gas sampling $\left({ }^{\circ} \mathrm{C}\right) ; k$ is the time conversion factor $\left(60 \mathrm{~min} \mathrm{~h}^{-1}\right)$.

\section{Soil nucleic acid extraction and cDNA synthesis}

Nucleic acid extraction and cDNA synthesis methods were described in our previously study (Hu et al., 2021b). Briefly, Soil genomic DNA and RNA were extracted using the DNeasy PowerSoil Kit and RNeasy PowerSoil Total RNA Kit (Qiagen, Hilden, Germany), respectively, according to the manufacturer's protocol. DNA and RNA concentrations were quantified using the NanoDrop One spectrophotometry (NanoDrop Technologies, Wilmington, DE). RNA was checked for DNA contamination by attempting to PCR amplify amo $A$ genes; samples that produced a negative electrophoresis result (i.e., no DNA contamination) were used for reverse transcription. cDNA was produced with RNA as the template using SuperScript IV Reverse Transcriptase and random hexamer primers (Invitrogen, Paisley, UK) according to the manufacturer's protocol. RNA was stored at $-80^{\circ} \mathrm{C}$; DNA and cDNA samples were stored at $-20^{\circ} \mathrm{C}$.

\section{Quantitative analysis of $a m o A$ genes and gene transcripts}

Quantitative PCR (qPCR) of AOB amoA genes and transcripts were performed on a CFX96 Optical Real-Time Detection System (Bio-Rad, Laboratories Inc., Hercules, CA, USA) using the primer pair amoA-1F (5'- GGGGTTTCTACTGGTGGT -3') and amoA-2R (5'CCCCTCKGSAAAGCCTTCTTC -3') (Rotthauwe et al., 1997) as we have previously described (Hu et al., 2021a).

\section{amo $A$ gene amplicon sequencing}

A two-step PCR was used for amoA amplicon sequencing library preparation. We used methods similar to our previous study on nifH genes (Hu et al., 2021b) for the amoA genes. First, amo $A$ 


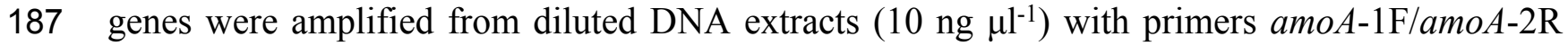

188

189

190

191

192

193

194

195

196

197

198

199

200

201

202

203

204

205

206

207

208

209

210

211

212

213

214

215

216

217

\section{Statistical analysis}

219

220

221

222

223

224

\section{Bioinformatics analysis} PRJNA733230.

containing Illumina-compatible adapters (Klindworth et al., 2013). The amplifications were performed in a $25-\mu 1$ mixture containing $12.5 \mu \mathrm{l} \mathrm{KAPA} \mathrm{HiFi} \mathrm{HotStart} \mathrm{ReadyMix} \mathrm{(2×)} \mathrm{(Kapa}$ Biosystems), $1 \mu \mathrm{l}$ of each primer (final concentration of $0.4 \mu \mathrm{M}$ ), $2.5 \mu \mathrm{l}$ of template DNA, and 8 $\mu \mathrm{l}$ of PCR grade nuclease-free water. The PCR protocol was: $95^{\circ} \mathrm{C}$ for $3 \mathrm{~min}$, then 35 cycles of $98^{\circ} \mathrm{C}$ for $20 \mathrm{~s}, 58^{\circ} \mathrm{C}$ for $15 \mathrm{~s}$ and $72^{\circ} \mathrm{C}$ for $15 \mathrm{~s}$, followed by $72^{\circ} \mathrm{C}$ for $5 \mathrm{~min}$. PCR products were purified using SparQ PureMag Beads (Quantabio). For the second step, index PCR was performed in a $50-\mu \mathrm{L}$ reaction containing $25 \mu \mathrm{KAPA}$ HiFi HotStart ReadyMix (2×) (Kapa Biosystems), 5 $\mu 1$ of each forward/ reverse NexteraxT index/primer, $5 \mu \mathrm{l}$ of PCR product from the first step as template DNA, and $10 \mu \mathrm{l}$ of PCR grade nuclease-free water. The PCR protocol was: $95^{\circ} \mathrm{C}$ for 3 min, then 8 cycles of $95^{\circ} \mathrm{C}$ for $30 \mathrm{~s}, 55^{\circ} \mathrm{C}$ for $30 \mathrm{~s}$ and $72^{\circ} \mathrm{C}$ for $30 \mathrm{~s}$, followed by $72^{\circ} \mathrm{C}$ for $5 \mathrm{~min}$. PCR products were purified using SparQ PureMag Beads, quantified by NanoDrop, pooled, and run on an Agilent Bioanalyzer to ensure quality (Hu et al., 2021b). $2 \times 275$-bp paired-ends sequencing was run on an Illumina Miseq platform (Illumina, CA, U.S.) in the University of Tennessee Genomics Core laboratory.

amoA sequences were processed using Mothur v.1.39.5 (Schloss et al., 2009). Forward and reverse reads were merged using make.contigs. Primer sequences were trimmed using trim.seqs. Read were removed using screen.seqs if the overlap region of the merged reads was less than $10 \mathrm{bp}$, if the reads were shorter than $400 \mathrm{bp}$, or if the reads contained any ambiguous bases. Similar to the pipeline used in our previous study (Hu et al., 2021b), chimera.uchime was used to remove chimeras based on a manually created database containing 9682 AOB amoA gene reference sequences FunGene (http://fungene.cme.msu.edu/) (Fish et al., 2013). For all downstream analyses, all libraries were subsampled to 4307 reads to uniform the sequencing depth. Operational taxonomic units (OTUs) were classified based on $97 \%$ nucleotide sequence similarity (Wang et al., 2014; Zheng et al., 2014) using vsearch in QIIME2-2019.7 (Bolyen et al., 2019). Singletons (OTUs appearing only once across all samples) were removed, and representative sequences for each OTU were selected. Abundant OTU representative sequences (total reads $\geq 100$ ) were blasted against the FunGene AOB amoA-like database using BLASTn. The raw sequencing data can be accessed from NCBI Sequence Read Archive (SRA) Database with BioProject accession number

The statistical analyses methods used in this research were similar to our previous study (Hu et al., 2021b). Diversity analyses of AOB community were performed with QIIME2-2019.7. Chao1, observed OTUs, Shannon index, and Pielou's evenness were calculated to determine alphadiversity (Gourmelon et al., 2016; He et al., 2013). A weighted-UniFrac method (Lozupone et al., 2007) was used for analyzing beta-diversity, similar to our previous study (Hu et al., 2021b). Permutational multivariate analysis of variance (PERMANOVA) was used to examine beta- 
225

226

227

228

229

230

231

232

233

234

235

236

237

238

239

240

241

242

243

244

245

246

247

248

249

250

251

252

253

254

255

256

257

258

259

260

261

diversity by treatment factors (Hu et al., 2021b). A neighbor-joining phylogenetic tree was constructed by QIIME using representative sequences of 28 abundant OTUs (OTUs with total reads $\geq 100$ ) and was visualized using Interactive Tree of Life (iTOL, v5) (Letunic \& Bork, 2011) as described in our previous study (Hu et al., 2021b). Principal coordinates analysis (PCoA) and redundancy analyses (RDA) based on weighted-UniFrac distances was performed in R 3.6.1 (The R Foundation for Statistical Computing) with packages vegan (2.5-5) and phyloseq.

A mixed model ANOVA within the GLIMMIX procedure in SAS 9.4 (SAS Inst., Cary, NC, USA) was performed to test treatment effects on soil properties, abundance and expression of amo $A$ genes, and alpha-diversity of AOB communities, similar to our previous approach ( $\mathrm{Hu}$ et al., 2021b). Gene and transcript abundances were log transformed to achieve normal distributions. Fixed effects included sampling season, $\mathrm{N}$ fertilization rate, and grass species, as well as their interactions. Random effects included the block and block by grass species. A least significant difference (LSD) method was used to compare the means of each two groups. Pearson correlation analyses were performed in IBM SPSS Statistics v26 (Hu et al., 2021b). IBM SPSS Amos 27.0 software was used to perform the structural equation modeling (SEM) to characterize interactions among measured variables. We followed the procedures of developing and modifying a structural equation model in ( $\mathrm{Li}$ et al., 2019; Hu et al., 2021b). Because community is a theoretical concept and not directly measurable. The "AOB community" component of the SEM model was a latent variable inferred from the measured relative abundances of the top 28 most abundant amoA OTUs (OTUs with $\geq 100$ reads, which comprised $97.9 \%$ of the total reads and were were classified into four species (Nitrosospira sp. 56-18, Nitrosospira sp. APG3, Nitrosospira multiformis, and Nitrosospira sp. Nsp14). For grass species, we defined switchgrass $=1$, big bluestem $=2$ due to the higher biomass of big bluestem than switchgrass. A well fit model should have a Chi-square/Df value in the range of 1.0 to 3.0 with probability level $>0.05$, RMSEA value $<0.05$, and fit indices (TLI, IFI, and CFI) both $>0.95$ (Blunch, 2012; Hooper et al., 2007; Kline, 2015).

\section{Results}

\section{Soil physicochemical characteristics, $\mathrm{N}_{2} \mathrm{O}$ emission, and nitrification potential}

The soil physicochemical characteristics under different treatment combinations were described in detail in our previous study (Hu et al., 2021b). Briefly, SWC, DOC, and DON showed significant differences by sampling season $(p<0.001$ for SWC and DOC; $p=0.006$ for DON) (Table 1; Table S1). SWC was highest $\left(0.30 \pm 0.01 \mathrm{~g} \mathrm{H}_{2} \mathrm{O} \mathrm{g}{ }^{-1}\right.$ dry weight soil $\left.\left[\mathrm{gdw}^{-1}\right]\right)$ at initial grass harvest $(\mathrm{H} 1)$ and lowest $\left(0.15 \pm 0.01 \mathrm{~g} \mathrm{H}_{2} \mathrm{O} \mathrm{gdw}{ }^{-1}\right)$ at second grass harvest (H2). DOC and DON were highest $\left(223.00 \pm 5.47 \mu \mathrm{g} \mathrm{gdw}^{-1}\right.$ and $22.44 \pm 1.98 \mu \mathrm{g} \mathrm{gdw}{ }^{-1}$, respectively) at $\mathrm{H} 2$ and lowest (163.85 $\pm 4.07 \mu \mathrm{gdw}^{-1}$ and $16.16 \pm 0.65 \mu \mathrm{g} \mathrm{gdw}^{-1}$, respectively) at H1 (Table S1) (Hu et al., 2021b).

Nitrogen fertilization rate and $\mathrm{C}_{4}$ grass species affected several soil properties (Table 1). With 
262 increased $\mathrm{N}$ fertilization rate, $\mathrm{NO}_{3}{ }^{-} \mathrm{N}$ increased from $0.39 \pm 0.16$ to $2.77 \pm 0.39 \mu \mathrm{g} \mathrm{gdw}^{-1}$, soil $\mathrm{pH}$ 263 decreased from $6.36 \pm 0.05$ to $6.12 \pm 0.05$, and DOC decreased from $210.18 \pm 8.60$ to $186.07 \pm$ $2645.23 \mu \mathrm{g} \mathrm{gdw}^{-1}$. Soil $\mathrm{pH}$ was higher under switchgrass $(6.32 \pm 0.05)$ compared to big bluestem (6.19 $265 \pm 0.03)$. Fertilized plots had higher SWC and lower C:N for switchgrasss than $0 \mathrm{~N}$ plots. In contrast, 266 fertilization of big bluestem resulted in lower SWC and no change in C:N (Table S1).

$267 \mathrm{~N}_{2} \mathrm{O}$ emission rate was affected by the interaction of sampling season, $\mathrm{N}$ fertilization rate, and 268 grass species (Table 1; Table S1): at H1, $\mathrm{N}_{2} \mathrm{O}-\mathrm{N}$ increased with N-rate, from $10.01 \pm 2.00$ to 23.77 $269 \pm 2.08 \mathrm{~g} \mathrm{~N}_{2} \mathrm{O}-\mathrm{N} \mathrm{ha}{ }^{-1} \mathrm{~d}^{-1}$ in switchgrass plots and from $8.74 \pm 3.92$ to $74.98 \pm 29.33 \mathrm{~g} \mathrm{~N}_{2} \mathrm{O}-\mathrm{N}$ ha ${ }^{-1}$ $270 \mathrm{~d}^{-1}$ in big bluestem plots; but at $\mathrm{G}$ and $\mathrm{H} 2$, no effect of $\mathrm{N}$ fertilization rate and grass species on $271 \quad \mathrm{~N}_{2} \mathrm{O}-\mathrm{N}$ was observed.

272 There was a significant interaction effect between sampling season and $\mathrm{N}$ fertilization rate on 273 nitrification potential (Table 1; Table S1): at G, nitrification potential was not significantly 274 different under different N-rates, but at $\mathrm{H} 1$ and $\mathrm{H} 2$, nitrification potential was significantly higher 275 under $202 \mathrm{~N}$. Nitrification potential was significantly higher in switchgrass plots $(0.14 \pm 0.02 \mu \mathrm{g}$ $\left.276 \mathrm{NO}_{2}-\mathrm{N} \mathrm{gdw}^{-1} \mathrm{~h}^{-1}\right)$ than in big bluestem plots $\left(0.10 \pm 0.02 \mu \mathrm{g} \mathrm{NO}_{2}-\mathrm{N} \mathrm{gdw}^{-1} \mathrm{~h}^{-1}\right)$ (Fig. 1; Table S1).

\section{Abundances of $a m o A$ genes and transcripts}

278 amo $A$ gene abundances significantly varied with $\mathrm{N}$ fertilization rate, and grass species (Table 1). 279 In general, amo $A$ gene abundances were lowest at $\mathrm{H} 1\left(2.51 \times 10^{5}\right.$ copies g$^{-1}$ dry weight soil [gdw $\left.\left.{ }^{-1}\right]\right)$ 280 and highest at $\mathrm{H} 2\left(1.14 \times 10^{7}\right.$ copies $\left.\mathrm{gdw}^{-1}\right)($ Fig. $2 A)$. N fertilization increased amo $A$ gene 281 abundance $\left(5.03 \times 10^{6}\right.$ and $7.00 \times 10^{6}$ copies $\mathrm{gdw}^{-1}$ for $67 \mathrm{~N}$ and $202 \mathrm{~N}$, respectively) compared to 282 no $\mathrm{N}$ addition $\left(1.70 \times 10^{6}\right.$ copies $\left.\mathrm{gdw}^{-1}\right)($ Fig. $2 \mathrm{~B})$. In addition, amo $A$ genes were more abundant 283 in switchgrass plots $\left(5.34 \times 10^{6}\right.$ copies $\left.\mathrm{gdw}^{-1}\right)$ than in big bluestem plots $\left(3.81 \times 10^{6}{\text { copies } \mathrm{gdw}^{-}}^{-}\right.$ $\left.284^{1}\right)(p=0.0066)($ Fig. 2C).

285

286

287

288

289

290

291

292

293

294

295

296

amo $A$ gene transcript abundances were significantly affected by the interaction effect of sampling season and $\mathrm{N}$ fertilization rate (Table 1): at $\mathrm{G}$, amoA transcript abundance was not different between N-rates; at $\mathrm{H} 1$, amo $A$ transcript abundance was highest under $67 \mathrm{~N}$; at $\mathrm{H} 2$, amo $A$ transcript abundances increased with increasing fertilizer. Grass species did not affect amo $A$ transcript abundance (Table 1 and Fig. 2C).

\section{Ammonia-oxidizing bacterial structure and community}

Using a 97\% sequence similarity cutoff, a total of 215,943 high-quality bacterial amo $A$ gene sequences were clustered into 538 OTUs, with 28 to 134 OTUs per sample. $\mathrm{N}$ fertilization rate and grass species significantly affected the alpha-diversity of AOB community (Table S2). AOB species richness (observed OTUs, Chaol) was lower at $\mathrm{H} 1$, but alpha-diversity estimates were similar across sampling times (Fig. 3A). Observed OTUs, Shannon index, and Pielou's evenness increased with $\mathrm{N}$ fertilization rate (Fig. 3B). Higher richness was observed in switchgrass plots 
297 than in big bluestem plots (Fig. 3C).

298

299

300

301

302

303

304

305

306

307

308

309

310

311

312

313

314

315

316

317

318

319

320

321

322

323

324

325

326

327

328

329

330

331

332

AOB community structure was significantly affected by $\mathrm{N}$ fertilization rate and grass species (Table 2; Fig. 4). N fertilization rate had stronger effect (PERMANOVA $R^{2}=0.504, p=0.001$ ) than grass species $\left(R^{2}=0.042, p=0.021\right)$ (Table 2). PCoA showed that AOB community composition in $202 \mathrm{~N}$ was different from $0 \mathrm{~N}$ and $67 \mathrm{~N}$ treatments (PERMANOVA $p<0.001$ ). Under $0 \mathrm{~N}$ and $67 \mathrm{~N}$, the communities were much more variable under big bluestem compared to switchgrass (Fig. 4).

\section{Phylogenetic analysis of ammonia-oxidizing bacterial community}

There were 28 abundant $a m o A$ OTUs (OTUs with $\geq 100$ reads) which comprised $97.9 \%$ of the total reads. A neighbor-joining phylogenetic tree showed that most of the 28 abundant amo $A$ OTUs classified as Nitrosospira, with 8 OTUs (accounting for $11.8 \%$ of total reads) classified as Nitrosospira multiformis (Fig. 5). Many amoA OTUs were treatment-specific; for example, 8 OTUs (OTU4, OTU8, OTU9, OTU10, OTU12, OTU16, OTU19, and OTU22) classified as Nitrosospira multiformis and 2 OTUs (OTU11, OTU23) classified as Nitrosospira sp. 56-18 were more abundant in $202 \mathrm{~N}$ compared to $67 \mathrm{~N}$ or $0 \mathrm{~N}$. OTU19 was only detected in big bluestem plots with 202N, whereas OTU3 and OTU6, belonging to Nitrosospira sp. Nsp14, were more abundant under $0 \mathrm{~N}$ and $67 \mathrm{~N}$ in big bluestem plots. OTU2 (classified as Nitrosospira sp. Nsp14) had higher relative abundance under $0 \mathrm{~N}$ and $67 \mathrm{~N}$ in both switchgrass and big bluestem plots (Fig. 5).

\section{Relationships between soil properties and AOB populations}

The abundance of amoA genes and transcripts were not correlated to each other (Table S3). The amo $A$ gene abundance was negatively correlated to soil $\mathrm{pH}(\mathrm{R}=-0.303, p<0.05), \mathrm{SWC}(\mathrm{R}=$ $0.792, p<0.01), \mathrm{NH}_{4}{ }^{+}-\mathrm{N}(\mathrm{R}=-0.471, p<0.01)$ but positively correlated to DOC $(\mathrm{R}=0.477, p<$ $0.01)$, $\mathrm{DON}(\mathrm{R}=0.445, p<0.01)$, and nitrification potential $(\mathrm{R}=0.530, p<0.01)$. In contrast, the amo $A$ gene transcript abundance was positively correlated to $\mathrm{SWC}(\mathrm{R}=0.561, p<0.01)$, and available inorganic $\mathrm{N}\left(\mathrm{NH}_{4}{ }^{+}-\mathrm{N}: \mathrm{R}=0.448, p<0.01 ; \mathrm{NO}_{3}{ }^{-} \mathrm{N}: \mathrm{R}=0.339, p<0.05\right)$, and negatively correlated to DOC $(\mathrm{R}=-0.640, p<0.01)$ (Table S3). Alpha-diversity indices (except Chao1 index) were negatively correlated to soil $\mathrm{pH}$ but positively correlated to $\mathrm{NO}_{3}{ }^{-}-\mathrm{N}$ and nitrification potential (Table S3). The Chaol index, observed OTUs, and Shannon index were positively correlated to amoA gene abundance but not transcript abundance (Table S3).

Structural equation modeling (SEM) was conducted to identify the impacts of soil physicochemical parameters on AOB populations (Fig. 6; Table S4). SWC had a direct negative effect on amo $A$ gene abundance (standardized path coefficient $=-0.711, p<0.001$ ) and a direct positive effect on amo $A$ transcript abundance $(0.433, p=0.010)$. amo $A$ transcript abundance was directly and positively affected by $\mathrm{NH}_{4}{ }^{+}-\mathrm{N}$ concentration $(0.331, p=0.002)$ but directly and negatively affected by DOC $(-0.493, p<0.001)$. In addition, amo $A$ gene abundance had a direct positive effect on its transcript abundance $(0.541, p<0.001)$. The Chaol index was directly and 
333 negatively affected by $\mathrm{NO}_{3}-\mathrm{N}(-0.366, p<0.001)$, whereas the Pielou's evenness of AOB 334 community was directly and positively affected by $\mathrm{NH}_{4}{ }^{+}-\mathrm{N}(0.268, p<0.001) . \mathrm{N}_{2} \mathrm{O}$ emission rates 335 were directly and positively affected by SWC $(0.723, p<0.001)$ and $\mathrm{NH}_{4}{ }^{+}-\mathrm{N}(0.167, p=0.022)$. 336 The total effects of $\mathrm{N}$ fertilization rate on amoA gene and transcript abundances, alpha-diversity 337 of AOB community, nitrification potential and $\mathrm{N}_{2} \mathrm{O}$ emission rate were positive (Table S5). For 338 the most abundant species within the AOB community, the total effects of $\mathrm{N}$ fertilization rate were 339 positive for Nitrosospira sp. 56-18, Nitrosospira multiformis, and Nitrosospira sp. APG3 but 340 negative for Nitrosospira sp. Nsp14. Compared to big bluestem, switchgrass had higher amoA gene and transcript abundances, alpha-diversity of AOB community, nitrification potential, and soil $\mathrm{NO}_{3}{ }^{-}-\mathrm{N}$ content but grass species had no effect on AOB community composition (composed of the four Nitrosospira species mentioned above).

344

345

346

347

348

349

350

351

352

353

354

355

356

357

358

359

360

361

362

363

364

365

366

367

368

369

370

371

A redundancy analysis (RDA) showed that soil physicochemical properties, amoA gene and transcript abundances, sampling season, $\mathrm{N}$ fertilization rate, grass species, and alpha-diversity indices measured in this study explained a total of $62.5 \%$ of the variability of AOB community structures, with the first two axes explaining $50.2 \%$ of this variability (Fig. 7). Soil pH, $\mathrm{NO}_{3}^{-}-\mathrm{N}$, $\mathrm{N}_{2} \mathrm{O}$ emission, nitrification potential, amoA transcript abundance, $\mathrm{N}$ fertilization rate, grass species, and alpha-diversity significantly correlated to the variability of AOB community structures $(p<0.05)$ (Fig. 7).

\section{Discussion}

We investigated the impacts of $\mathrm{N}$ fertilization and native grass species on the seasonal population size, activity, alpha-diversity, and community structure of AOB. AOB population size, activity, and species richness varied with sampling time, but AOB community structure was relatively constant. Nitrogen fertilization significantly promoted the abundance, activity, and alpha-diversity of $\mathrm{AOB}$ as well as nitrification potential, as it provided ammonium as initial substrate for nitrification process. Notably, the promotion of AOB activity by $\mathrm{N}$ addition was only observed in grass growing season (June, August) and not at grass green up (April, before $\mathrm{N}$ fertilization), indicating that urea fertilization may only have short-term influence on AOB activity. Moreover, $\mathrm{NO}_{3}^{-}-\mathrm{N}$, a product of nitrification, was closely and positively related to AOB activity and was significantly higher under high N-rate.

Our observations that $\mathrm{N}$ management can affect $\mathrm{AOB}$ community structure is consistent with previous studies (Mendum \& Hirsch, 2002; Rooney et al., 2010; Webster et al., 2005). The influence of $\mathrm{N}$ fertilization on $\mathrm{AOB}$ communities can be partly explained by the lower soil $\mathrm{pH}$ at 202N (Pommerening-Roser \& Koops, 2005; Xi et al., 2017): oxidation of ammonium produces $\mathrm{H}^{+}$ ions that acidify the soil and may select for more acidic-tolerant AOBs. Indeed, in this study we observed a very different AOB community structure under high N-rate compared to moderate or no $\mathrm{N}$ fertilization. In particular, we found that OTUs classified as Nitrosospira multiformis were more abundant at the high urea fertilization rate. The genome of $N$. multiformis contains genes encoding urease, urea carboxylase, and a putative allophanate (carboxyurea) hydrolase for urea 
372 conversion to ammonium and bicarbonate (Norton et al., 2008). The ureolytic capacity of $N$. 373 multiformis makes it well-adapted for soils undergoing urea fertilization and/or acidic $\mathrm{pH}$ (Burton 374 \& Prosser, 2001; Pommerening-Roser \& Koops, 2005). Furthermore, the arginine decarboxylases 375 in N. multiformis are known to function in acid-tolerance (Norton et al., 2008). It is unknown if 376 the other Nitrosospira species we found in these soils contain urease and arginine decarboxylase.

377 AOB population size and species richness, as well as nitrification potential, were significantly 378 higher under switchgrass compared to big bluestem. The AOB community structure was also 379 significantly different between the two grasses. This suggests that plants may play important roles 380 in shaping AOB communities and selecting distinct AOB populations. Root exudates of grasses

381

382

383

384

385

386

387

388

389

390

391

392

393

394

395

396

397

398

399

400

401

402

403

404

405

406

407

408

409

410 contain active compounds, such as organic acids, which may inhibit nitrification (Subbarao et al., 2009), and difference in the types or concentrations of compounds from the two grass species may have influenced the soil microbial communities. Moreover, leached compounds from litter, such as phenolics, tannins or monoterpenes, may also have had different effects on: 1) the inhibition to ammonium monooxygenase (Elroy \& Sunil, 1973; White, 1986); 2) the promotion to ammonium immobilization by heterotrophs decreasing ammonium availability for AOB (Bremner \& McCarty, 1993); or 3) the quality of soil organic carbon under different grass species (Strauss \& Lamberti, 2002). Big bluestem has a higher cellulose content than switchgrass (Delaquis et al., 2014), which suggest that we may see lower nitrification rates and/or AOB population size in switchgrass plots. However, our results showed that switchgrass had higher AOB abundance and nitrification potential as well as similar AOB activity compared to big bluestem. One possible explanation was that switchgrass tends to mature earlier than big bluestem (Mitchell \& Anderson, 2008). When we sampled soils, the switchgrass had become stemmy and contained more cellulose as it matured (Lemus, 2008), which made its litter more difficult to decompose, and therefore reducing competition for ammonium from heterotrophic decomposers (Strauss \& Lamberti, 2002). Lastly, the significant difference in AOB community structure but similar activity between switchgrass and big bluestem suggests that nitrification may be controlled by taxonomically different nitrifiers, and is indicative of functional redundancy within AOB communities (Louca et al., 2016; Louca et al., 2018; Short et al., 2013). It was notable that our SEM result predicted a lower abundance, activity, and alpha-diversity of AOB, as well as nitrification potential and soil nitrate content under big bluestem than under switchgrass, suggesting a lower potential for $\mathrm{N}$ losses through nitrate leaching and $\mathrm{N}_{2} \mathrm{O}$ emission in big bluestem systems.

AOB population dynamics were related to soil moisture in our study. The significant negative correlation of amoA gene abundance but positive correlation of amoA transcript abundance with SWC found in this study was also observed in a cotton field in the similar climatic zone (Hu et al., 2021a). One possible explanation was that increasing SWC decreases soil oxygen, resulting in decreased abundances of aerobic AOB. The increased activity we observed could be because AOB populations increased expression of amo $A$ genes under oxygen stress. It has been found that the transcription of bacterial amoA genes can be promoted in soils with $>70 \%$ water filled pore space (Theodorakopoulos et al., 2017). Another study also reported that low dissolved oxygen content 
411 can promote amoA gene transcription in Nitrosomonas europaea in culture (Yu \& Chandran, 412 2010).

413 Dissolved organic C (DOC) is another key factor that may have influenced the variation of AOB 414 abundance and activity, which was highest at second grass harvest, and negatively associated with 415 SWC, indicating possible leaching loss or dilution of DOC under higher SWC conditions (Poll et 416 al., 2008; Zibilske \& Makus, 2009). Total precipitation during the initial harvest period (June, $417161.29 \mathrm{~mm}$ ) was higher than during grass green up and second harvest (April and August, 94.23 418 and $120.14 \mathrm{~mm}$, respectively). Our study found that the population size of AOB increased with 419 DOC concentration, which was also observed in some other agroecosystems (Hu et al., 2021a; Sun 420 et al., 2019) and in groundwater (van der Wielen et al., 2009). One possible explanation might be 421 that under DOC-rich conditions, mineralization of organic $\mathrm{C}$ by heterotrophs provided more $\mathrm{CO}_{2}$ 422 for the autotrophic AOB. However, there was a negative correlation between DOC and amo $A$ 423 transcript abundance in our study, which was also observed in estuarine ecosystems (Happel et al., 424 2019). Many studies have observed that nitrification rates can be inhibited by increased organic $\mathrm{C}$ 425 concentration in terrestrial ecosystems due to 1) biological nitrification inhibition (Elroy \& Sunil, 426 1973; Janke et al., 2018; Subbarao et al., 2009; White, 1986); 2) phenolics, tannins, and 427 monoterpenes promoting heterotrophic immobilization of ammonium and decreasing substrate 428 availability for nitrifiers (Bremner \& McCarty, 1993; Paavolainen et al., 1998); and 3) the 429 increased competition between heterotrophic and nitrifying bacteria for ammonium caused by high 430 quality C (i.e., labile carbon) (Strauss \& Lamberti, 2002).

Similar to DOC, DON is also an important factor affecting AOB abundance and can be diluted or lost under high SWC conditions. There was a positive correlation between DON and AOB abundance in our study, which may be that the DON, especially low molecular weight DON, provides initial substrate for nitrification (Jones et al., 2004). However, no correlation between DON and AOB activity was observed, indicating that the expression of amo $A$ may be influenced by other climatic factors, such as temperature, soil texture, and other soil characteristics.

Nitrification potential was positively correlated to amo $A$ gene abundances, confirming the reliability of using nitrification potential to infer the population size of nitrifiers (Belser \& Mays, 1980; Bernhard et al., 2010). However, nitrification potential was not correlated to amoA transcript abundance, indicating that in situ AOB activity is likely influenced by climatic factors, nutrient content, and soil properties (Lew et al., 2019; Nelson et al., 2016). Although many studies have observed a positive correlation between the abundance of ammonia oxidizers and $\mathrm{N}_{2} \mathrm{O}$ emissions (Breuillin-Sessoms et al., 2017; Pannu et al., 2019), other studies, including ours, report no correlation of $\mathrm{N}_{2} \mathrm{O}$ emissions with $\mathrm{AOB}$ abundance and activity (Lourenco et al., 2018; Pereira et al., 2015). This is probably due to the fact that $\mathrm{N}_{2} \mathrm{O}$ emissions are regulated by both nitrification and denitrification processes through nitrifiers (AOB, AOA, and comammox bacteria) and 448 denitrifiers (Maag \& Vinther, 1996). We found that amoA transcript abundances significantly and positively associated to its gene abundance according to the SEM, indicating that AOB population 
449 size does affect its activity. Furthermore, the alpha-diversity of AOB communities was strongly 450 and positively correlated to AOB population size and nitrification potential but had no correlation 451 with AOB activity, suggesting that a more diverse AOB community may have more nitrification 452 potential but may not influence in situ nitrification rate due to functional redundancy and 453 454 455

We determined the dynamics of AOB population size, activity, alpha-diversity, and community 458 environmental stress.

\section{Conclusions} structure under different $\mathrm{N}$ fertilization rates and $\mathrm{C}_{4}$ grass species in a native perennial grassland. The genus Nitrosospira was the dominant AOB in this grassland. In accordance with our hypothesis, elevated $\mathrm{N}$ fertilizer application changed $\mathrm{AOB}$ community composition and increased abundance, activity, and alpha-diversity of AOB community as well as nitrification potential, $\mathrm{N}_{2} \mathrm{O}$ emissions, soil nitrate content, and soil acidity. This suggests high $\mathrm{N}$ addition in native $\mathrm{C}_{4}$ grass systems may have negative consequences for $\mathrm{N}$ retention. The SEM predicted lower abundance, activity, and alpha-diversity of AOB, as well as nitrification potential and soil nitrate content under big bluestem compared to switchgrass, suggesting a lower potential for $\mathrm{N}$ losses. Together, our work revealed insights into important relationships among the abundance, activity, alpha-diversity, and community structure of $\mathrm{AOB}$ and their responses to $\mathrm{N}$ fertilization in perennial native $\mathrm{C}_{4}$ grass systems.

\section{Acknowledgements}

The authors are grateful to B.J. Delozier, Cody Fust, Nicholas Tissot, Charles Summey, and Bobby Simpson and the staff of the East Tennessee Research and Education Center who manage and maintain the field trials, Sreejata Bandopadhyay for field sampling, Sutie Xu, Shikha Singh and Surendra Singh for data collection, and Mallari Starrett and Tori Beard for assistance in the laboratory.

\section{References}

Araki, N., Yamaguchi, T., Yamazaki, S., \& Harada, H. (2004). Quantification of amoA gene abundance and their amoA mRNA levels in activated sludge by real-time PCR. Water Science and Technology, 50(8), 1-8. https://doi.org/10.2166/wst.2004.0474

Avrahami, S., Liesack, W., \& Conrad, R. (2003). Effects of temperature and fertilizer on activity and community structure of soil ammonia oxidizers. Environmental Microbiology, 5(8), 691-705. https://doi.org/10.1046/j.1462-2920.2003.00457.x

Bakken, L. R., \& Frostegård, A. (2020). Emerging options for mitigating $\mathrm{N}_{2} \mathrm{O}$ emissions from food production by manipulating the soil microbiota. Current Opinion in Environmental Sustainability, 47, 89-94. https://doi.org/10.1016/j.cosust.2020.08.010

Bandopadhyay, S., Liquet, Y. G. J. E., Henderson, K. B., Anunciado, M. B., Hayes, D. G., \& DeBruyn, J. M. (2020). Soil Microbial Communities Associated With Biodegradable Plastic Mulch Films. Frontiers in Microbiology, 11, 587074. https://doi.org/10.3389/fmicb.2020.587074 
488

489

490

491

492

493

494

495

496

497

498

499

500

501

502

503

504

505

506

507

508

509

510

511

512

513

514

515

516

517

518

519

520

521

522

523

524

525

526

527

528

529

530

Bartosch, S., Hartwig, C., Spieck, E., \& Bock, E. (2002). Immunological detection of Nitrospiralike bacteria in various soils. Microbial Ecology, 43(1), 26-33. https://doi.org/10.1007/s00248-001-0037-5

Beeckman, F., Motte, H., \& Beeckman, T. (2018). Nitrification in agricultural soils: impact, actors and mitigation. Current Opinion in Biotechnology, 50, 166-173. https://doi.org/10.1016/j.copbio.2018.01.014

Belser, L. W., \& Mays, E. L. (1980). Specific inhibition of nitrite oxidation by chlorate and its use in assessing nitrification in soils and sediments. Applied and environmental microbiology, 39(3), 505-510. https://doi.org/10.1128/AEM.39.3.505-510.1980

Bernhard, A. E., Landry, Z. C., Blevins, A., de la Torre, J. R., Giblin, A. E., \& Stahl, D. A. (2010). Abundance of ammonia-oxidizing archaea and bacteria along an estuarine salinity gradient in relation to potential nitrification rates. Applied and Environmental Microbiology, 76(4), 1285-1289. https://doi.org/10.1128/AEM.02018-09

Blunch, N. (2012). Introduction to structural equation modeling using IBM SPSS statistics and AMOS. Sage.

Bolyen, E., Rideout, J. R., Dillon, M. R., Bokulich, N. A., Abnet, C. C., Al-Ghalith, G. A., Alexander, H., Alm, E. J., Arumugam, M., Asnicar, F., Bai, Y., Bisanz, J. E., Bittinger, K., Brejnrod, A., Brislawn, C. J., Brown, C. T., Callahan, B. J., Caraballo-Rodríguez, A. M., Chase, J., Cope, E. K., Da Silva, R., Diener, C., Dorrestein, P. C., Douglas, G. M., Durall, D. M., Duvallet, C., Edwardson, C. F., Ernst, M., Estaki, M., Fouquier, J., Gauglitz, J. M., Gibbons, S. M., Gibson, D. L., Gonzalez, A., Gorlick, K., Guo, J., Hillmann, B., Holmes, S., Holste, H., Huttenhower, C., Huttley, G. A., Janssen, S., Jarmusch, A. K., Jiang, L., Kaehler, B. D., Kang, K. B., Keefe, C. R., Keim, P., Kelley, S. T., Knights, D., Koester, I., Kosciolek, T., Kreps, J., Langille, M. G. I., Lee, J., Ley, R., Liu, Y.-X., Loftfield, E., Lozupone, C., Maher, M., Marotz, C., Martin, B. D., McDonald, D., Mclver, L. J., Melnik, A. V., Metcalf, J. L., Morgan, S. C., Morton, J. T., Naimey, A. T., Navas-Molina, J. A., Nothias, L. F., Orchanian, S. B., Pearson, T., Peoples, S. L., Petras, D., Preuss, M. L., Pruesse, E., Rasmussen, L. B., Rivers, A., Robeson, M. S., Rosenthal, P., Segata, N., Shaffer, M., Shiffer, A., Sinha, R., Song, S. J., Spear, J. R., Swafford, A. D., Thompson, L. R., Torres, P. J., Trinh, P., Tripathi, A., Turnbaugh, P. J., Ul-Hasan, S., van der Hooft, J. J. J., Vargas, F., Vázquez-Baeza, Y., Vogtmann, E., von Hippel, M., Walters, W., Wan, Y., Wang, M., Warren, J., Weber, K. C., Williamson, C. H. D., Willis, A. D., Xu, Z. Z., Zaneveld, J. R., Zhang, Y., Zhu, Q., Knight, R., \& Caporaso, J. G. (2019). Reproducible, interactive, scalable and extensible microbiome data science using QIIME 2. Nature Biotechnology, 37(8), 852-857. https://doi.org/10.1038/s41587019-0209-9

Brejda, J. J. (2000). Fertilization of native warm-season grasses. Native warm-season grasses: research trends and issues, 177-200. https://doi.org/10.2135/cssaspecpub30.c12 (CSSA Special Publications)

Bremner, J., \& McCarty, G. (1993). Inhibition of nitrification in soil by allelochemicals derived from plants and plant residues. Soil biochemistry, 8, 181-218.

Breuillin-Sessoms, F., Venterea, R. T., Sadowsky, M. J., Coulter, J. A., Clough, T. J., \& Wang, P. (2017). Nitrification gene ratio and free ammonia explain nitrite and nitrous oxide 
531

532

533

534

535

536

537

538

539

540

541

542

543

544

545

546

547

548

549

550

551

552

553

554

555

556

557

558

559

560

561

562

563

564

565

566

567

568

569

570

571

572

573

production in urea-amended soils. Soil Biology and Biochemistry, 111, 143-153. https://doi.org/10.1016/j.soilbio.2017.04.007

Burton, S. A., \& Prosser, J. I. (2001). Autotrophic ammonia oxidation at low pH through urea hydrolysis. Applied and Environmental Microbiology, 67(7), 2952-2957. https://doi.org/10.1128/AEM.67.7.2952-2957.2001

Cameron, K. C., Di, H. J., \& Moir, J. L. (2013). Nitrogen losses from the soil/plant system: a review. Annals of Applied Biology, 162(2), 145-173. https://doi.org/10.1111/aab.12014

Collier, S. M., Ruark, M. D., Oates, L. G., Jokela, W. E., \& Dell, C. J. (2014). Measurement of greenhouse gas flux from agricultural soils using static chambers. Journal of Visualized Experiments(90). https://doi.org/10.3791/52110

Conrad, R. (1996). Soil microorganisms as controllers of atmospheric trace gases $\left(\mathrm{H}_{2}, \mathrm{CO}, \mathrm{CH}_{4}\right.$, OCS, $\mathrm{N}_{2} \mathrm{O}$, and NO). Microbiological Reviews, 60(4), 609-640.

Daims, H., Lebedeva, E. V., Pjevac, P., Han, P., Herbold, C., Albertsen, M., Jehmlich, N., Palatinszky, M., Vierheilig, J., Bulaev, A., Kirkegaard, R. H., von Bergen, M., Rattei, T., Bendinger, B., Nielsen, P. H., \& Wagner, M. (2015). Complete nitrification by Nitrospira bacteria. Nature, 528(7583), 504-509. https://doi.org/10.1038/nature16461

Davidson, E. A. (2009). The contribution of manure and fertilizer nitrogen to atmospheric nitrous oxide since 1860. Nature Geoscience, 2(9), 659-662. https://doi.org/10.1038/ngeo608

Delaquis, E., Samson, R., Seguin, P., Mustafa, A., \& Martel, H. (2014). Impacts of improved switchgrass and big bluestem selections on yield, morphological characteristics, and biomass quality. Advances in Agriculture, 2014, 192824. https://doi.org/10.1155/2014/192824

Di, H. J., \& Cameron, K. C. (2002). Nitrate leaching in temperate agroecosystems: sources, factors and mitigating strategies. Nutrient Cycling in Agroecosystems, 64(3), 237-256. https://doi.org/10.1023/A:1021471531188

Di, H. J., Cameron, K. C., Shen, J. P., Winefield, C. S., O'Callaghan, M., Bowatte, S., \& He, J. Z. (2009). Nitrification driven by bacteria and not archaea in nitrogen-rich grassland soils. Nature Geoscience, 2(9), 621-624. https://doi.org/10.1038/ngeo613

Duan, Y.-F., Kong, X.-W., Schramm, A., Labouriau, R., Eriksen, J., \& Petersen, S. O. (2017). Microbial $\mathrm{N}$ transformations and $\mathrm{N}_{2} \mathrm{O}$ emission after simulated grassland cultivation: effects of the nitrification inhibitor 3,4-dimethylpyrazole phosphate (DMPP). Applied and Environmental Microbiology, 83(1), e02019-02016. https://doi.org/10.1128/AEM.0201916

Elroy, L. R., \& Sunil, K. P. (1973). Inhibition of nitrification by climax ecosystems. II. additional evidence and possible role of tannins. American Journal of Botany, 60(7), 691-702. https://doi.org/10.1002/j.1537-2197.1973.tb05975.x

Faulwetter, J. L., Burr, M. D., Parker, A. E., Stein, O. R., \& Camper, A. K. (2013). Influence of season and plant species on the abundance and diversity of sulfate reducing bacteria and ammonia oxidizing bacteria in constructed wetland microcosms. Microbial Ecology, 65(1), 111-127. https://doi.org/10.1007/s00248-012-0114-y

Fike, J. H., Parrish, D. J., Wolf, D. D., Balasko, J. A., Green Jr, J. T., Rasnake, M., \& Reynolds, J. H. (2006). Long-term yield potential of switchgrass-for-biofuel systems. Biomass and Bioenergy, 30(3), 198-206. 
574 Fish, J. A., Chai, B., Wang, Q., Sun, Y., Brown, C. T., Tiedje, J. M., \& Cole, J. R. (2013).

575

576

577

578

579

580

581

582

583

584

585

586

587

588

589

590

591

592

593

594

595

596

597

598

599

600

601

602

603

604

605

606

607

608

609

610

611

612

613

614

615

616

617 FunGene: the functional gene pipeline and repository. Frontiers in Microbiology, 4, 291. https://doi.org/10.3389/fmicb.2013.00291

Francis, G. S., Haynes, R. J., Speir, T. W., \& Williams, P. H. (1995). The effects of a nitrification inhibitor on leaching losses and recovery of mineralized nitrogen by a wheat crop after ploughing-in temporary leguminous pastures. Fertilizer Research, 41(1), 33-39. https://doi.org/10.1007/BF00749518

Friesen, P. C., \& Cattani, D. J. (2017). Nitrogen use efficiency and productivity of first year switchgrass and big bluestem from low to high soil nitrogen. Biomass and Bioenergy, 107, 317-325. https://doi.org/https://doi.org/10.1016/j.biombioe.2017.10.016

Frijlink, M., Abee, T., Laanbroek, H., Boer, W., \& Konings, W. (1992). The bioenergetics of ammonia and hydroxylamine oxidation in Nitrosomonas europaea at acid and alkaline pH. Archives of Microbiology, 157(2), 194-199. https://doi.org/10.1007/BF00245290

Gourmelon, V., Maggia, L., Powell, J. R., Gigante, S., Hortal, S., Gueunier, C., Letellier, K., \& Carriconde, F. (2016). Environmental and geographical factors structure soil microbial diversity in New Caledonian ultramafic substrates: a metagenomic approach. PLoS One, 11(12), e0167405. https://doi.org/10.1371/journal.pone.0167405

Hallin, S., Philippot, L., Loffler, F. E., Sanford, R. A., \& Jones, C. M. (2018). Genomics and ecology of novel $\mathrm{N}_{2} \mathrm{O}$-reducing microorganisms. Trends Microbiol, 26(1), 43-55. https://doi.org/10.1016/j.tim.2017.07.003

Hansen, E. M., Eriksen, J., \& Vinther, F. P. (2007). Catch crop strategy and nitrate leaching following grazed grass-clover. Soil use and management, 23(4), 348-358. https://doi.org/10.1111/j.1475-2743.2007.00106.x

Happel, E. M., Markussen, T., Teikari, J. E., Huchaiah, V., Alneberg, J., Andersson, A. F., Sivonen, K., Middelboe, M., Kisand, V., \& Riemann, L. (2019). Effects of allochthonous dissolved organic matter input on microbial composition and nitrogen-cycling genes at two contrasting estuarine sites. FEMS Microbiology Ecology, 95(9). https://doi.org/10.1093/femsec/fiz123

He, Y., Zhou, B.-J., Deng, G.-H., Jiang, X.-T., Zhang, H., \& Zhou, H.-W. (2013). Comparison of microbial diversity determined with the same variable tag sequence extracted from two different PCR amplicons. BMC Microbiology, 13(1), 208. https://doi.org/10.1186/14712180-13-208

Hooper, D., Coughlan, J., \& Mullen, M. (2007). Structural equation modeling: Guidelines for determining model fit. The Electronic Journal of Business Research Methods, 6.

Hu, J., Jin, V. L., Konkel, J. Y. M., Schaeffer, S. M., Schneider, L. G., \& DeBruyn, J. M. (2021a). Soil health management enhances microbial nitrogen cycling capacity and activity. mSphere, 6(1), e01237-01220. https://doi.org/10.1128/mSphere.01237-20

Hu, J., Richwine, J. D., Keyser, P. D., Li, L., Yao, F., Jagadamma, S., \& DeBruyn, J. M. (2021b). Nitrogen fertilization and native $\mathrm{C}_{4}$ grass species alter abundance, activity, and diversity of soil diazotrophic communities. Frontiers in Microbiology, 12, 675693. https://doi.org/10.3389/fmicb.2021.675693

Janke, C. K., Wendling, L. A., \& Fujinuma, R. (2018). Biological nitrification inhibition by root exudates of native species, Hibiscus splendens and Solanum echinatum. PeerJ, 6, e4960-e4960. https://doi.org/10.7717/peerj.4960 
618

619

620

621

622

623

624

625

626

627

628

629

630

631

632

633

634

635

636

637

638

639

640

641

642

643

644

645

646

647

648

649

650

651

652

653

654

655

656

657

658

659

660

Jia, Z., \& Conrad, R. (2009). Bacteria rather than archaea dominate microbial ammonia oxidation in an agricultural soil. Environmental Microbiology, 11(7), 1658-1671. https://doi.org/10.1111/j.1462-2920.2009.01891.x

Jones, D. L., Shannon, D., V. Murphy, D., \& Farrar, J. (2004). Role of dissolved organic nitrogen (DON) in soil N cycling in grassland soils. Soil Biology and Biochemistry, 36(5), 749-756. https://doi.org/10.1016/j.soilbio.2004.01.003

Klindworth, A., Pruesse, E., Schweer, T., Peplies, J., Quast, C., Horn, M., \& Glockner, F. O. (2013). Evaluation of general $16 \mathrm{~S}$ ribosomal RNA gene PCR primers for classical and next-generation sequencing-based diversity studies. Nucleic Acids Res, 41(1), e1. https://doi.org/10.1093/nar/gks808

Kline, R. B. (2015). Principles and practice of structural equation modeling. Guilford publications.

Kong, A. Y., Hristova, K., Scow, K. M., \& Six, J. (2010). Impacts of different N management regimes on nitrifier and denitrifier communities and $\mathrm{N}$ cycling in soil microenvironments. Soil Biology and Biochemistry, 42(9), 1523-1533. https://doi.org/10.1016/j.soilbio.2010.05.021

Kowalchuk, G. A., Stienstra, A. W., Heilig, G. H., Stephen, J. R., \& Woldendorp, J. W. (2000). Molecular analysis of ammonia-oxidising bacteria in soil of successional grasslands of the Drentsche A (The Netherlands). FEMS Microbiology Ecology, 31(3), 207-215. https://www.ncbi.nlm.nih.gov/pubmed/10719201

Leininger, S., Urich, T., Schloter, M., Schwark, L., Qi, J., Nicol, G. W., Prosser, J. I., Schuster, S. C., \& Schleper, C. (2006). Archaea predominate among ammonia-oxidizing prokaryotes in soils. Nature, 442(7104), 806-809. https://doi.org/10.1038/nature04983

Lemus, R. (2008). Establishing and managing switchgrass as a forage. Forage News. Mississippi State University Extension Service.

Letunic, I., \& Bork, P. (2011). Interactive Tree Of Life v2: online annotation and display of phylogenetic trees made easy. Nucleic Acids Res, 39(Web Server issue), W475-478. https://doi.org/10.1093/nar/gkr201

Levy-Booth, D. J., Prescott, C. E., \& Grayston, S. J. (2014). Microbial functional genes involved in nitrogen fixation, nitrification and denitrification in forest ecosystems. Soil Biology and Biochemistry, 75, 11-25. https://doi.org/10.1016/j.soilbio.2014.03.021

Lew, S., Glińska-Lewczuk, K., \& Lew, M. (2019). The effects of environmental parameters on the microbial activity in peat-bog lakes. PLoS One, 14(10), e0224441-e0224441. https://doi.org/10.1371/journal.pone.0224441

Li, L., Wilson, C. B., He, H., Zhang, X., Zhou, F., \& Schaeffer, S. M. (2019). Physical, biochemical, and microbial controls on amino sugar accumulation in soils under longterm cover cropping and no-tillage farming. Soil Biology and Biochemistry, 135, 369-378. https://doi.org/10.1016/j.soilbio.2019.05.017

Liu, R., Hu, H., Suter, H., Hayden, H. L., He, J., Mele, P., \& Chen, D. (2016). Nitrification is a primary driver of nitrous oxide production in laboratory microcosms from different landuse soils. Frontiers in Microbiology, 7. https://doi.org/10.3389/fmicb.2016.01373

Louca, S., Jacques, S. M. S., Pires, A. P. F., Leal, J. S., Srivastava, D. S., Parfrey, L. W., Farjalla, V. F., \& Doebeli, M. (2016). High taxonomic variability despite stable functional

Peer) reviewing PDF | (2021:09:65305:1:1:NEW 25 Oct 2021) 
661

662

663

664

665

666

667

668

669

670

671

672

673

674

675

676

677

678

679

680

681

682

683

684

685

686

687

688

689

690

691

692

693

694

695

696

697

698

699

700

701

702

703

structure across microbial communities. Nature Ecology \& Evolution, 1(1).

https://doi.org/10.1038/s41559-016-0015

Louca, S., Polz, M. F., Mazel, F., Albright, M. B. N., Huber, J. A., O'Connor, M. I., Ackermann, M., Hahn, A. S., Srivastava, D. S., Crowe, S. A., Doebeli, M., \& Parfrey, L. W. (2018). Function and functional redundancy in microbial systems. Nature Ecology \& Evolution, 2(6), 936-943. https://doi.org/10.1038/s41559-018-0519-1

Lourenco, K. S., Cassman, N. A., Pijl, A. S., van Veen, J. A., Cantarella, H., \& Kuramae, E. E. (2018). Nitrosospira sp. govern nitrous oxide emissions in a tropical soil amended with residues of bioenergy crop. Frontiers in Microbiology, 9, 674. https://doi.org/10.3389/fmicb.2018.00674

Lozupone, C. A., Hamady, M., Kelley, S. T., \& Knight, R. (2007). Quantitative and qualitative beta diversity measures lead to different insights into factors that structure microbial communities. Applied and environmental microbiology, 73(5), 1576-1585. https://doi.org/10.1128/AEM.01996-06

Maag, M., \& Vinther, F. P. (1996). Nitrous oxide emission by nitrification and denitrification in different soil types and at different soil moisture contents and temperatures. Applied Soil Ecology, 4(1), 5-14. https://doi.org/https://doi.org/10.1016/0929-1393(96)00106-0

Mendum, T. A., \& Hirsch, P. R. (2002). Changes in the population structure of $\beta$-group autotrophic ammonia oxidising bacteria in arable soils in response to agricultural practice. Soil Biology and Biochemistry, 34(10), 1479-1485. https://doi.org/10.1016/S0038-0717(02)00092-5

Mitchell, R., \& Anderson, B. (2008). Switchgrass, big bluestem, and indiangrass for grazing and hay. University of Nebraska-Lincoln Extension, IANR NebGuide G, 1908.

Nelson, M. B., Martiny, A. C., \& Martiny, J. B. H. (2016). Global biogeography of microbial nitrogen-cycling traits in soil. Proceedings of the National Academy of Sciences, 113(29), 8033-8040. https://doi.org/10.1073/pnas.1601070113

Newell, L. (1968). Chemical Composition of Two Warm - Season Prairie Grasses in Three Environment 1. Crop Science, 8(3), 325-329.

Norton, J. M., Klotz, M. G., Stein, L. Y., Arp, D. J., Bottomley, P. J., Chain, P. S., Hauser, L. J., Land, M. L., Larimer, F. W., Shin, M. W., \& Starkenburg, S. R. (2008). Complete genome sequence of Nitrosospira multiformis, an ammonia-oxidizing bacterium from the soil environment. Applied and Environmental Microbiology, 74(11), 3559-3572. https://doi.org/10.1128/AEM.02722-07

Ouyang, Y., Norton, J. M., Stark, J. M., Reeve, J. R., \& Habteselassie, M. Y. (2016). Ammoniaoxidizing bacteria are more responsive than archaea to nitrogen source in an agricultural soil. Soil Biology and Biochemistry, 96, 4-15. https://doi.org/10.1016/j.soilbio.2016.01.012

Paavolainen, L., Kitunen, V., \& Smolander, A. (1998). Inhibition of nitrification in forest soil by monoterpenes. Plant and Soil, 205(2), 147-154. https://doi.org/10.1023/A:1004335419358

Pannu, M. W., Meinhardt, K. A., Bertagnolli, A., Fransen, S. C., Stahl, D. A., \& Strand, S. E. (2019). Nitrous oxide emissions associated with ammonia-oxidizing bacteria abundance in fields of switchgrass with and without intercropped alfalfa

Peer) reviewing PDF | (2021:09:65305:1:1:NEW 25 Oct 2021) 
704

705

706

707

708

709

710

711

712

713

714

715

716

717

718

719

720

721

722

723

724

725

726

727

728

729

730

731

732

733

734

735

736

737

738

739

740

741

742

743

744

745

746

747

[https://doi.org/10.1111/1758-2229.12790]. Environmental Microbiology Reports, 11(5), 727-735. https://doi.org/https://doi.org/10.1111/1758-2229.12790

Parrish, D. J., \& Fike, J. H. (2005). The biology and agronomy of switchgrass for biofuels. BPTS, 24(5-6), 423-459.

Pereira, E. I. P., Suddick, E. C., Mansour, I., Mukome, F. N. D., Parikh, S. J., Scow, K., \& Six, J. (2015). Biochar alters nitrogen transformations but has minimal effects on nitrous oxide emissions in an organically managed lettuce mesocosm. Biology and Fertility of Soils, 51(5), 573-582. https://doi.org/10.1007/s00374-015-1004-5

Poll, C., Marhan, S., Ingwersen, J., \& Kandeler, E. (2008). Dynamics of litter carbon turnover and microbial abundance in a rye detritusphere. Soil Biology and Biochemistry, 40(6), 1306-1321.

Pommerening-Roser, A., \& Koops, H. P. (2005). Environmental pH as an important factor for the distribution of urease positive ammonia-oxidizing bacteria. Microbiological Research, 160(1), 27-35. https://doi.org/10.1016/j.micres.2004.09.006

Prosser, J. I., Hink, L., Gubry-Rangin, C., \& Nicol, G. W. (2020). Nitrous oxide production by ammonia oxidizers: Physiological diversity, niche differentiation and potential mitigation strategies. Global Change Biology, 26(1), 103-118. https://doi.org/10.1111/gcb.14877

Prosser, J. I., Microbiology, S. f. G., \& Group, S. f. G. M. E. (1986). Nitrification. Society for General Microbiology. https://books.google.com/books?id=ollXAQAAIAAJ

Purkhold, U., Pommerening-Röser, A., Juretschko, S., Schmid, M. C., Koops, H.-P., \& Wagner, M. (2000). Phylogeny of all recognized species of ammonia oxidizers based on comparative 16S rRNA and amoA sequence analysis: implications for molecular diversity surveys. Applied and Environmental Microbiology, 66, 5368-5382.

Qin, D., Plattner, G., Tignor, M., Allen, S., Boschung, J., Nauels, A., Xia, Y., Bex, V., \& Midgley, P. (2014). Climate change 2013: the physical science basis. Contribution of Working Group I to the Fifth Assessment Report of the Intergovernmental Panel on Climate Change (eds TF Stocker et al.), 5-14.

Ravishankara, A. R., John, S. D., \& Robert, W. P. (2009). Nitrous oxide $\left(\mathrm{N}_{2} \mathrm{O}\right)$ : the dominant ozone-depleting substance emitted in the 21st century. Science (American Association for the Advancement of Science), 326(5949), 123-125. https://doi.org/10.1126/science.1176985

Rooney, D. C., Kennedy, N. M., Gleeson, D. B., \& Clipson, N. J. W. (2010). Responses of ammonia-oxidising bacterial communities to nitrogen, lime, and plant species in upland grassland soil. Applied and Environmental Soil Science, 2010, 1-7. https://doi.org/10.1155/2010/319721

Rotthauwe, J. H., Witzel, K. P., \& Liesack, W. (1997). The ammonia monooxygenase structural gene $a m o A$ as a functional marker: molecular fine-scale analysis of natural ammoniaoxidizing populations. Applied and Environmental Microbiology, 63(12), 4704.

Schleper, C., \& Nicol, G. W. (2010). Ammonia-oxidising archaea--physiology, ecology and evolution. Advances in Microbial Physiology, 57, 1-41. https://doi.org/10.1016/B978-012-381045-8.00001-1

Schloss, P. D., Westcott, S. L., Ryabin, T., Hall, J. R., Hartmann, M., Hollister, E. B., Lesniewski, R. A., Oakley, B. B., Parks, D. H., Robinson, C. J., Sahl, J. W., Stres, B., Thallinger, G. G., Van Horn, D. J., \& Weber, C. F. (2009). Introducing mothur: open- 
748

749

750

751

752

753

754

755

756

757

758

759

760

761

762

763

764

765

766

767

768

769

770

771

772

773

774

775

776

777

778

779

780

781

782

783

784

785

786

787

788

789

790 source, platform-independent, community-supported software for describing and comparing microbial communities. Applied and Environmental Microbiology, 75(23), 7537-7541. https://doi.org/10.1128/AEM.01541-09

Segal, L. M., Miller, D. N., McGhee, R. P., Loecke, T. D., Cook, K. L., Shapiro, C. A., \& Drijber, R. A. (2017). Bacterial and archaeal ammonia oxidizers respond differently to long-term tillage and fertilizer management at a continuous maize site. Soil and Tillage Research, 168, 110-117. https://doi.org/10.1016/j.still.2016.12.014

Short, M. D., Abell, G. C. J., Bodrossy, L., \& van den Akker, B. (2013). Application of a novel functional gene microarray to probe the functional ecology of ammonia oxidation in nitrifying activated sludge. PLoS One, 8(10), e77139-e77139. https://doi.org/10.1371/journal.pone.0077139

Smits, N. A. C., Hefting, M. M., Kamst-van Agterveld, M. P., Laanbroek, H. J., Paalman, A. J., \& Bobbink, R. (2010). Nitrification along a grassland gradient: Inhibition found in matgrass swards. Soil Biology and Biochemistry, 42(4), 635-641.

https://doi.org/10.1016/j.soilbio.2010.01.001

Stephen, J. R., McCaig, A. E., Smith, Z., Prosser, J. I., \& Embley, T. M. (1996). Molecular diversity of soil and marine 16S rRNA gene sequences related to beta-subgroup ammonia-oxidizing bacteria. Applied and Environmental Microbiology, 62(11), 41474154.

Strauss, E. A., \& Lamberti, G. A. (2002). Effect of dissolved organic carbon quality on microbial decomposition and nitrification rates in stream sediments. Freshwater Biology, 47(1), 6574. https://doi.org/10.1046/j.1365-2427.2002.00776.x

Subbarao, G. V., Nakahara, K., Hurtado, M. P., Ono, H., Moreta, D. E., Salcedo, A. F., Yoshihashi, A. T., Ishikawa, T., Ishitani, M., Ohnishi-Kameyama, M., Yoshida, M., Rondon, M., Rao, I. M., Lascano, C. E., Berry, W. L., Ito, O., \& William, H. S. (2009). Evidence for biological nitrification inhibition in Brachiaria pastures. Proceedings of the National Academy of Sciences, USA, 106(41), 17302-17307. https://doi.org/10.1073/pnas.0903694106

Subbarao, G. V., Rondon, M., Ito, O., Ishikawa, T., Rao, I. M., Nakahara, K., Lascano, C., \& Berry, W. L. (2006). Biological nitrification inhibition (BNI)—is it a widespread phenomenon? Plant and Soil, 294(1-2), 5-18. https://doi.org/10.1007/s11104-006-9159-3

Sun, R., Myrold, D. D., Wang, D., Guo, X., \& Chu, H. (2019). AOA and AOB communities respond differently to changes of soil $\mathrm{pH}$ under long-term fertilization. Soil Ecology Letters, 1(3-4), 126-135. https://doi.org/10.1007/s42832-019-0016-8

Syakila, A., \& Kroeze, C. (2011). The global nitrous oxide budget revisited. Greenhouse Gas Measurement and Management, 1(1), 17-26. https://doi.org/10.3763/ghgmm.2010.0007

Theodorakopoulos, N., Lognoul, M., Degrune, F., Broux, F., Regaert, D., Muys, C., Heinesch, B., Bodson, B., Aubinet, M., \& Vandenbol, M. (2017). Increased expression of bacterial amoA during an $\mathrm{N}_{2} \mathrm{O}$ emission peak in an agricultural field. Agriculture, Ecosystems \& Environment, 236, 212-220. https://doi.org/10.1016/j.agee.2016.12.002

van der Wielen, P., Voost, S., \& van der Kooij, D. (2009). Ammonia-oxidizing bacteria and archaea in groundwater treatment and drinking water distribution systems. Applied and environmental microbiology, 75, 4687-4695. https://doi.org/10.1128/AEM.00387-09

Peer) reviewing PDF | (2021:09:65305:1:1:NEW 25 Oct 2021) 
791

792

793

794

795

796

797

798

799

800

801

802

803

804

805

806

807

808

809

810

811

812

813

814

815

816

817

818

819

820

821

822

823

824

825

826

827

828

829

830

831

832

833

Venter, J. C., Remington, K., Heidelberg, J. F., Halpern, A. L., Rusch, D., Eisen, J. A., Wu, D., Paulsen, I., Nelson, K. E., Nelson, W., Fouts, D. E., Levy, S., Knap, A. H., Lomas, M. W., Nealson, K., White, O., Peterson, J., Hoffman, J., Parsons, R., Baden-Tillson, H., Pfannkoch, C., Rogers, Y. H., \& Smith, H. O. (2004). Environmental genome shotgun sequencing of the Sargasso Sea. Science, 304(5667), 66-74. https://doi.org/10.1126/science.1093857

Walker, C. B., de la Torre, J. R., Klotz, M. G., Urakawa, H., Pinel, N., Arp, D. J., BrochierArmanet, C., Chain, P. S., Chan, P. P., Gollabgir, A., Hemp, J., Hugler, M., Karr, E. A., Konneke, M., Shin, M., Lawton, T. J., Lowe, T., Martens-Habbena, W., Sayavedra-Soto, L. A., Lang, D., Sievert, S. M., Rosenzweig, A. C., Manning, G., \& Stahl, D. A. (2010). Nitrosopumilus maritimus genome reveals unique mechanisms for nitrification and autotrophy in globally distributed marine crenarchaea. Proc Natl Acad Sci U S A, 107(19), 8818-8823. https://doi.org/10.1073/pnas.0913533107

Wang, B., Zhao, J., Guo, Z., Ma, J., Xu, H., \& Jia, Z. (2014). Differential contributions of ammonia oxidizers and nitrite oxidizers to nitrification in four paddy soils. The ISME Journal, 9(5), 1062-1075. https://doi.org/10.1038/ismej.2014.194

Webster, G., Embley, T. M., Freitag, T. E., Smith, Z., \& Prosser, J. I. (2005). Links between ammonia oxidizer species composition, functional diversity and nitrification kinetics in grassland soils. Environmental Microbiology, 7(5), 676-684. https://doi.org/10.1111/j.1462-2920.2005.00740.x

Wertz, S., Leigh, A. K., \& Grayston, S. J. (2012). Effects of long-term fertilization of forest soils on potential nitrification and on the abundance and community structure of ammonia oxidizers and nitrite oxidizers. FEMS Microbiology Ecology, 79(1), 142-154. https://doi.org/10.1111/j.1574-6941.2011.01204.x

White, C. S. (1986). Volatile and water-soluble inhibitors of nitrogen mineralization and nitrification in a ponderosa pine ecosystem. Biology and fertility of soils, 2(2), 97-104. https://doi.org/10.1007/BF00257586

Xi, R., Long, X. E., Huang, S., \& Yao, H. (2017). pH rather than nitrification and urease inhibitors determines the community of ammonia oxidizers in a vegetable soil. AMB Express, 7(1), 129. https://doi.org/10.1186/s13568-017-0426-x

Xu, L., Cheng, S., Fang, H., Xin, X., Xu, X., \& Tang, H. (2019). Soil inorganic nitrogen composition and plant functional type determine forage crops nitrogen uptake preference in the temperate cultivated grassland, Inner Mongolia. Soil Science and Plant Nutrition, 65(5), 501-510. https://doi.org/10.1080/00380768.2019.1671777

Ying, J., Li, X., Wang, N., Lan, Z., He, J., \& Bai, Y. (2017). Contrasting effects of nitrogen forms and soil $\mathrm{pH}$ on ammonia oxidizing microorganisms and their responses to long-term nitrogen fertilization in a typical steppe ecosystem. Soil Biology and Biochemistry, 107, 10-18. https://doi.org/10.1016/j.soilbio.2016.12.023

Yu, R., \& Chandran, K. (2010). Strategies of Nitrosomonas europaea 19718 to counter low dissolved oxygen and high nitrite concentrations. BMC Microbiology, 10, 70. https://doi.org/10.1186/1471-2180-10-70

Zheng, Y., Huang, R., Wang, B. Z., Bodelier, P. L. E., \& Jia, Z. J. (2014). Competitive interactions between methane- and ammonia-oxidizing bacteria modulate carbon and

Peer) reviewing PDF | (2021:09:65305:1:1:NEW 25 Oct 2021) 
$834 \quad$ nitrogen cycling in paddy soil. Biogeosciences, 11(12), 3353-3368.

835 https://doi.org/10.5194/bg-11-3353-2014

836 Zibilske, L. M., \& Makus, D. J. (2009). Black oat cover crop management effects on soil

837 temperature and biological properties on a Mollisol in Texas, USA. Geoderma, 149(3-4),

838 379-385. https://doi.org/10.1016/j.geoderma.2009.01.001

839 
Figure 1

Seasonal dynamics of nitrification potential in relation to nitrogen fertilization rate and grass species.

G, grass green up; $H 1$, initial grass harvest; $H 2$, second grass harvest; $0 N$, no N fertilization;

67N, 67 kg N ha-1 fertilization; 202N, $202 \mathrm{~kg} \mathrm{~N}$ ha $^{-1}$ fertilization; SG, switchgrass; BB, big bluestem.

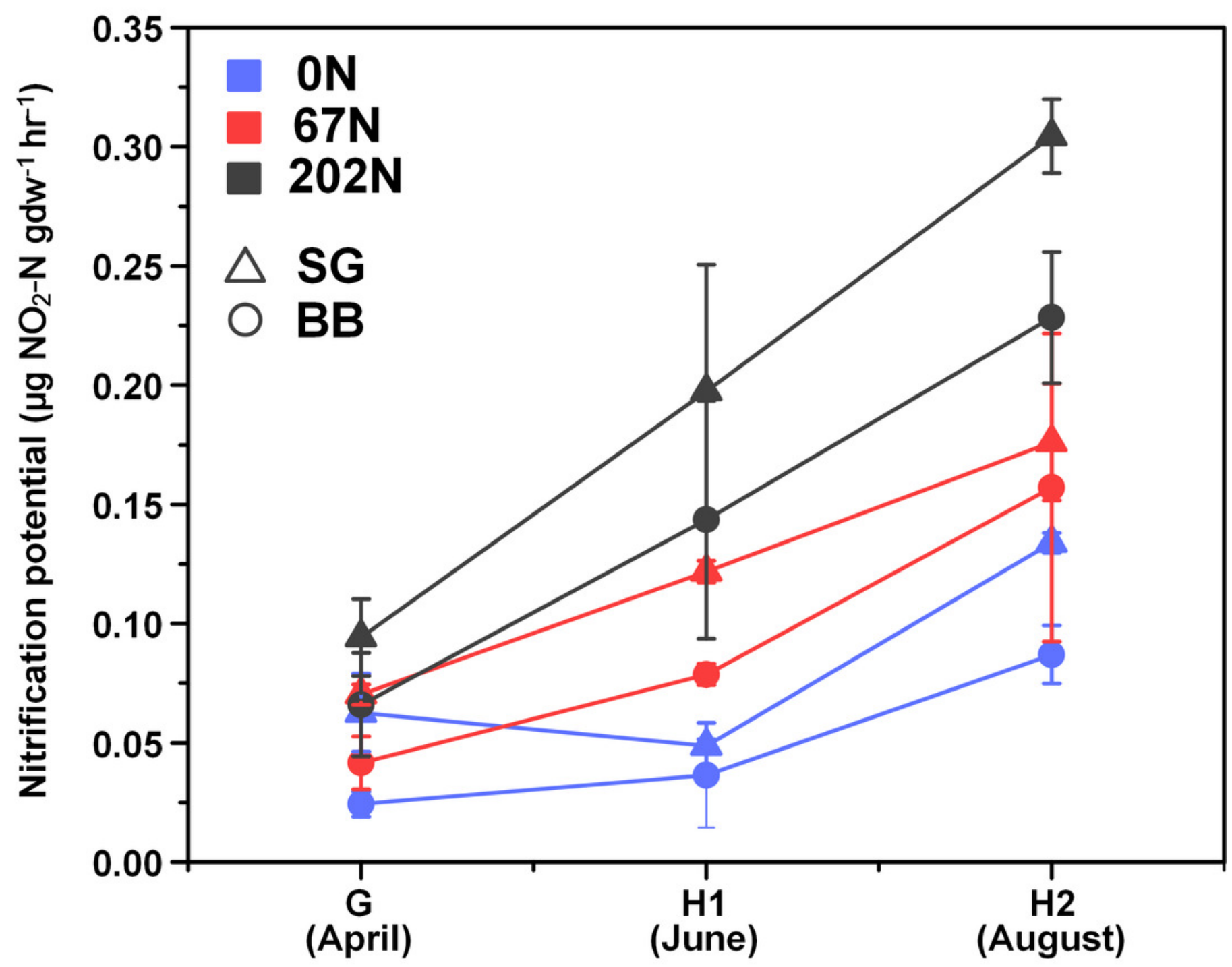




\section{Figure 2}

Absolute abundance of amoA gene (gray) and transcript (red) in relation to (A) sampling season; (B) nitrogen fertilization rates; and grass species.

Boxes represent the interquartile range (IQR). Lines within boxes represent median values. Whiskers represent the range between minimum and maximum values. Diamonds represent outliers outside of this range. Dots within boxes represent mean values. Different letters above (black, for gene abundance) or below (red, for transcript abundance) the boxes indicate significant differences between treatment levels within groups by comparing means using Least Significant Difference (LSD) tests $(\alpha=0.05)$. The letters were only shown for groups with significant differences. G, grass green up; $\mathrm{H} 1$, initial grass harvest; $\mathrm{H} 2$, second grass harvest; $0 \mathrm{~N}$, no $\mathrm{N}$ fertilization; $67 \mathrm{~N}, 67 \mathrm{~kg} \mathrm{~N}^{-1}$ fertilization; $202 \mathrm{~N}, 202 \mathrm{~kg} \mathrm{~N} \mathrm{ha}{ }^{-1}$ fertilization; SG, switchgrass; BB, big bluestem.
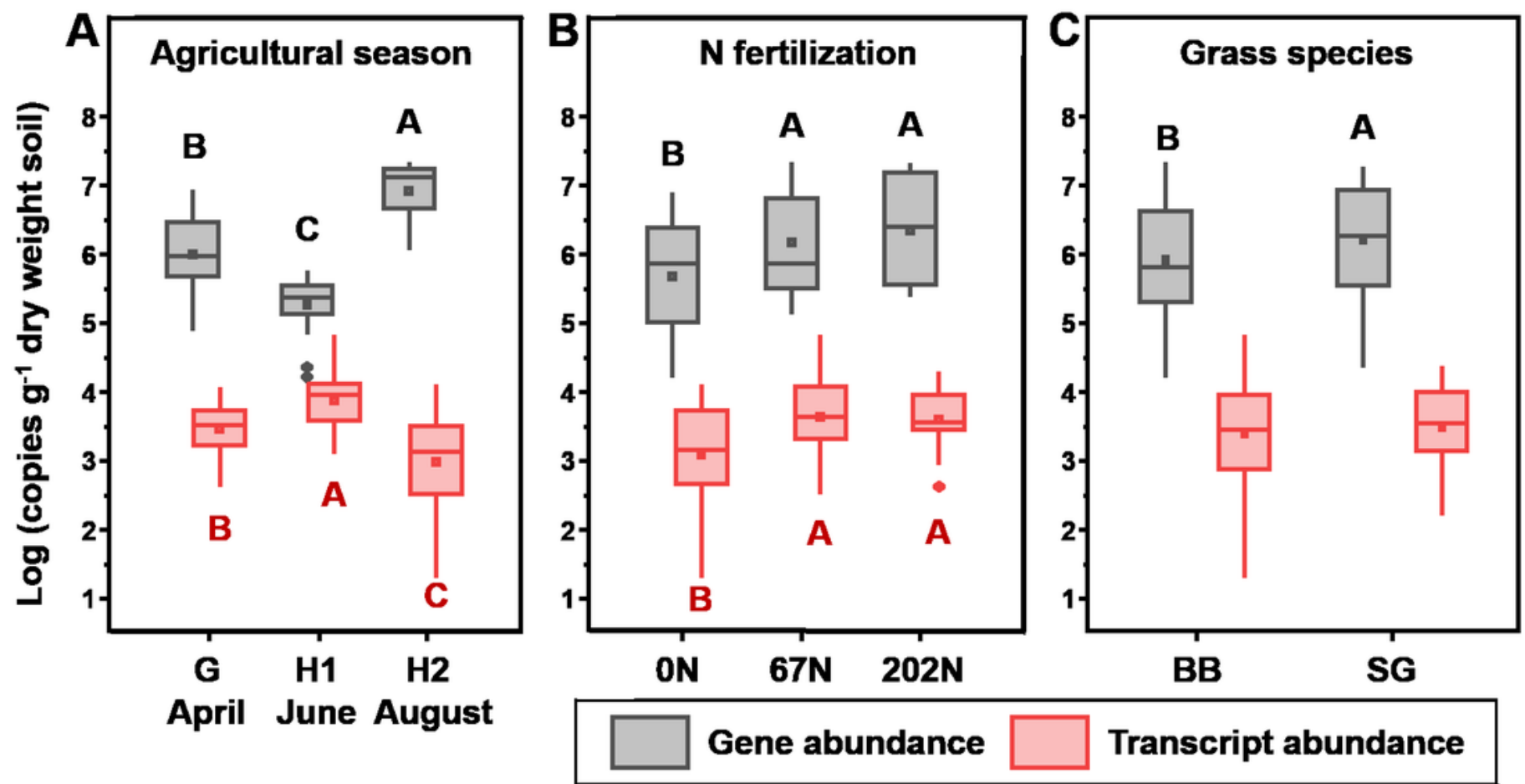


\section{Figure 3}

Alpha-diversity of ammonia-oxidizing bacterial communities in relation to (A) sampling seasons, (B) nitrogen fertilization rates, and (C) grass species.

Boxes represent the interquartile range (IQR). Lines within boxes represent median values. Whiskers represent the range between minimum and maximum values. Dots represent outliers outside of this range. Diamonds represent mean values. Different letters above boxes indicate significant differences between treatment levels within groups by comparing means using Least Significant Difference (LSD) tests $(\alpha=0.05)$. The letters were only shown in groups that have significant effects. $\mathrm{G}$, grass green up; $\mathrm{H} 1$, initial grass harvest; $\mathrm{H} 2$, second grass harvest; 0N, no N fertilization; $67 \mathrm{~N}, 67 \mathrm{~kg} \mathrm{~N}^{-1}$ fertilization; 202N, $202 \mathrm{~kg} \mathrm{~N}$ ha ${ }^{-1}$ fertilization; BB, big bluestem; SG, switchgrass. 

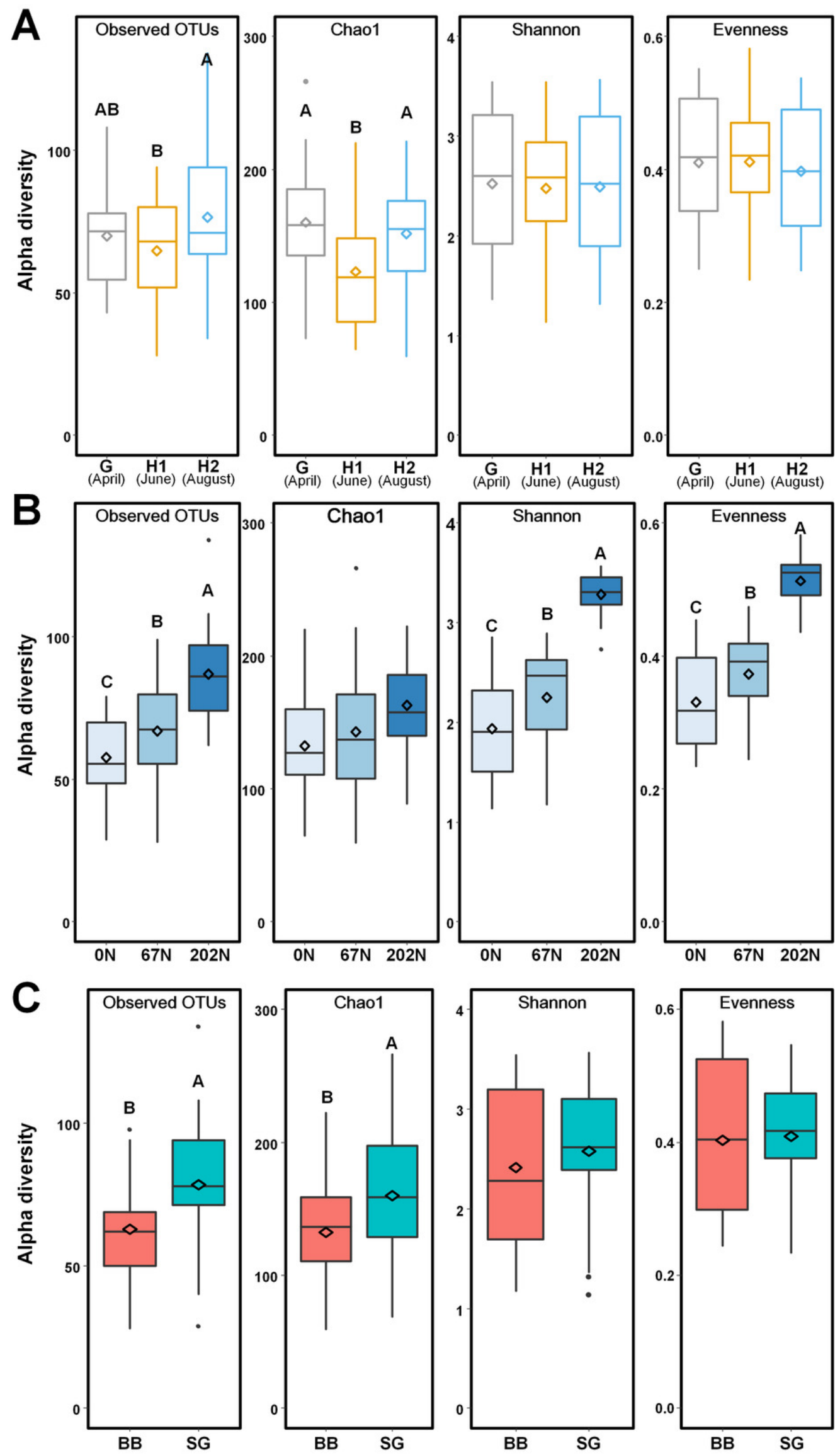

Peer) reviewing PDF | (2021:09:65305:1:1:NEW 25 Oct 2021) 
Figure 4

PCoA of weighted-UniFrac distance between ammonia-oxidizing bacterial communities based on sampling season, $\mathrm{N}$ fertilization rate, and grass species.

G, grass green up; $H 1$, initial grass harvest; $H 2$, second grass harvest; $0 N$, no N fertilization; 67N, $67 \mathrm{~kg} \mathrm{~N} \mathrm{ha}^{-1}$ fertilization; 202N, $202 \mathrm{~kg} \mathrm{~N} \mathrm{ha}^{-1}$ fertilization; SG, switchgrass; BB, big bluestem.

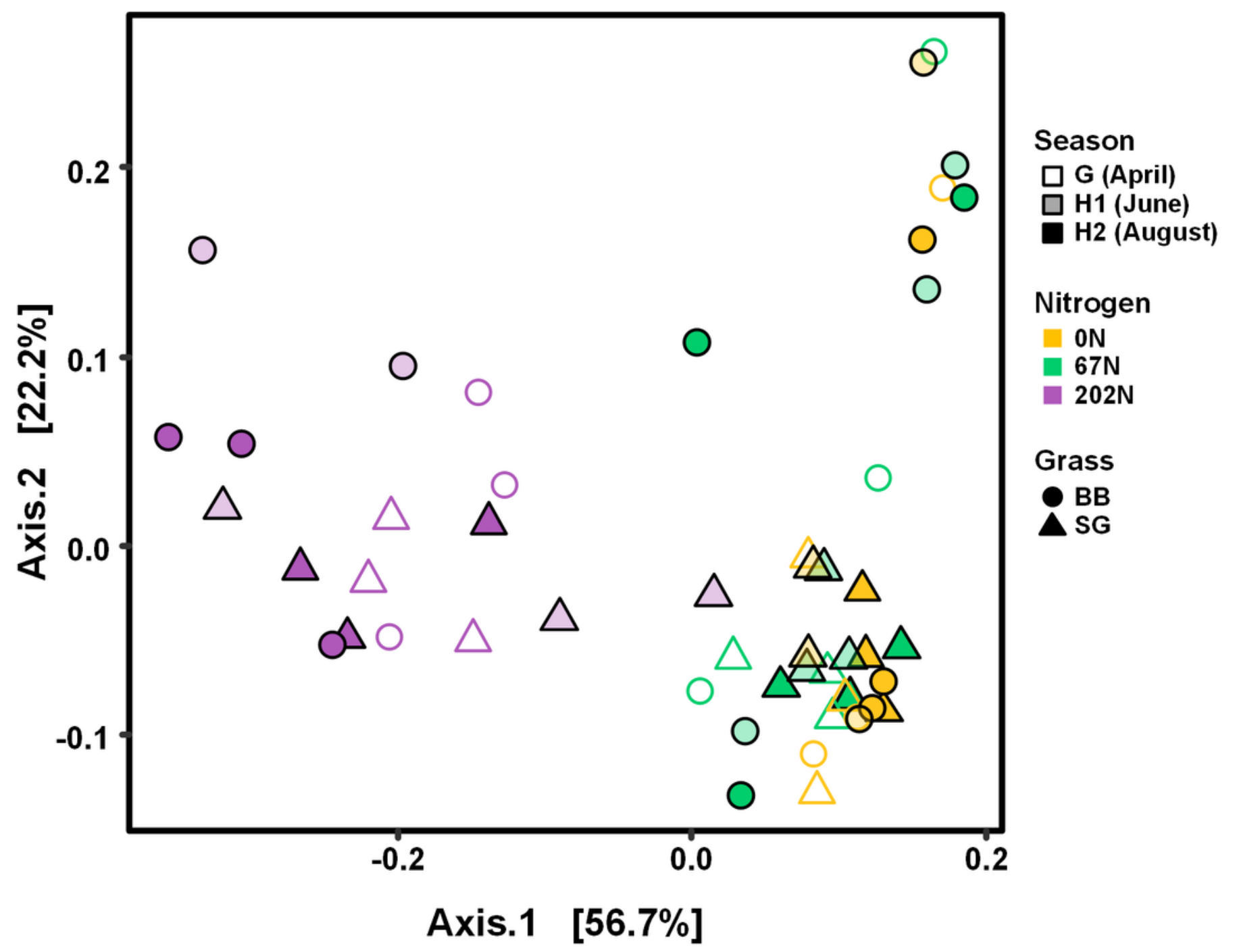




\section{Figure 5}

Neighbor-joining phylogenetic tree of the top 28 abundant amoA OTUs (OTUs with $\geq$ 100 reads).

Bootstrap values greater than $50 \%$ of 1000 resamplings are shown near nodes. The scale bar indicates 0.01 nucleotide substitutions per nucleotide position. The blue-and-white heatmap shows the logarithmic value of OTU relative abundances in percentages in different treatment combinations of $\mathrm{N}$ fertilization rate and grass species in different sampling seasons. The NA in the legend means no reads were detected. GenBank accession numbers are shown for sequences from other studies. G, grass green up; $H 1$, initial grass harvest; $H 2$, second grass harvest; 0N, no N fertilization; $67 \mathrm{~N}, 67 \mathrm{~kg} \mathrm{~N}^{-{ }^{-1}}$ fertilization; $202 \mathrm{~N}, 202 \mathrm{~kg} \mathrm{~N}$ ha ${ }^{-1}$ fertilization; SG, switchgrass; BB, big bluestem. 


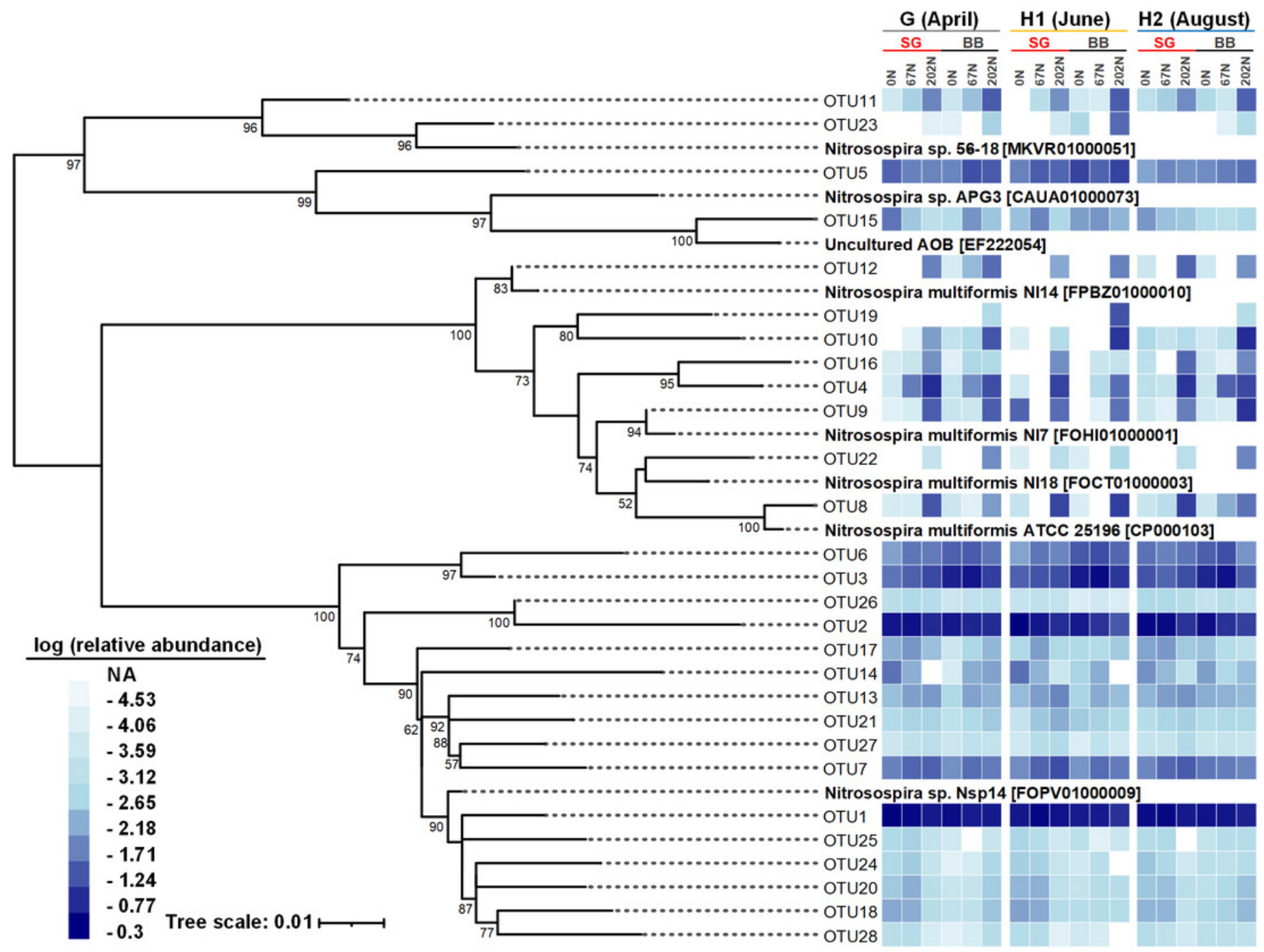


Figure 6

Structural equation modeling (SEM) for ammonia-oxidizing bacterial abundance, functional activity, and major community composition with key soil parameters.

Red arrows indicate positive relationships. Blue arrows indicate negative relationships. Single headed arrows represent causal relationship ( $p$-value $<0.05)$. The direction of arrow indicates the direction of causation. The width of arrow indicates the extent of effects, i.e., the standardized path coefficients proportional to the thickness of arrows. See Table S4 for specific standardized path coefficients and Table S5 for standardized total effects. SWC, soil water content; DOC, dissolved organic C; DON, dissolved organic N; TOC, total organic C; TN, total N.

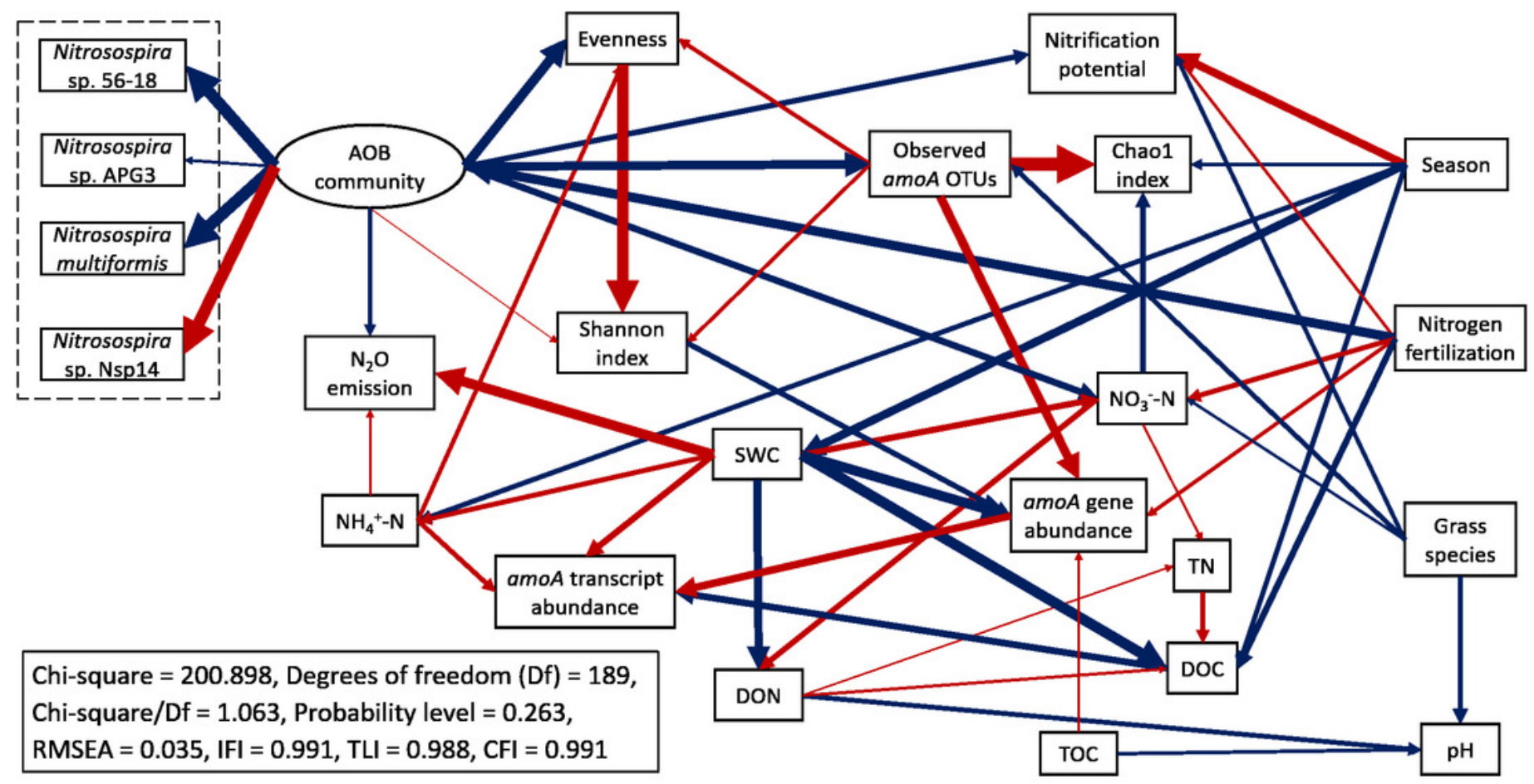




\section{Figure 7}

Redundancy analysis (RDA) of weighted-UniFrac distances between ammonia-oxidizing bacterial community structures (amoA OTU relative abundances).

Arrows represent loadings of environmental factors, amoA gene and transcript abundances, and community diversity metrics. $\mathrm{G}$, grass green up; $\mathrm{H} 1$, initial grass harvest; $\mathrm{H} 2$, second grass harvest; 0N, no N fertilization; 67N, $67 \mathrm{~kg} \mathrm{~N}$ ha $^{-1}$ fertilization; 202N, $202 \mathrm{~kg} \mathrm{~N}$ ha $^{-1}$ fertilization; SG, switchgrass; BB, big bluestem; grass, grass species; N-rate, $\mathrm{N}$ fertilization rate; NP, nitrification potential. 


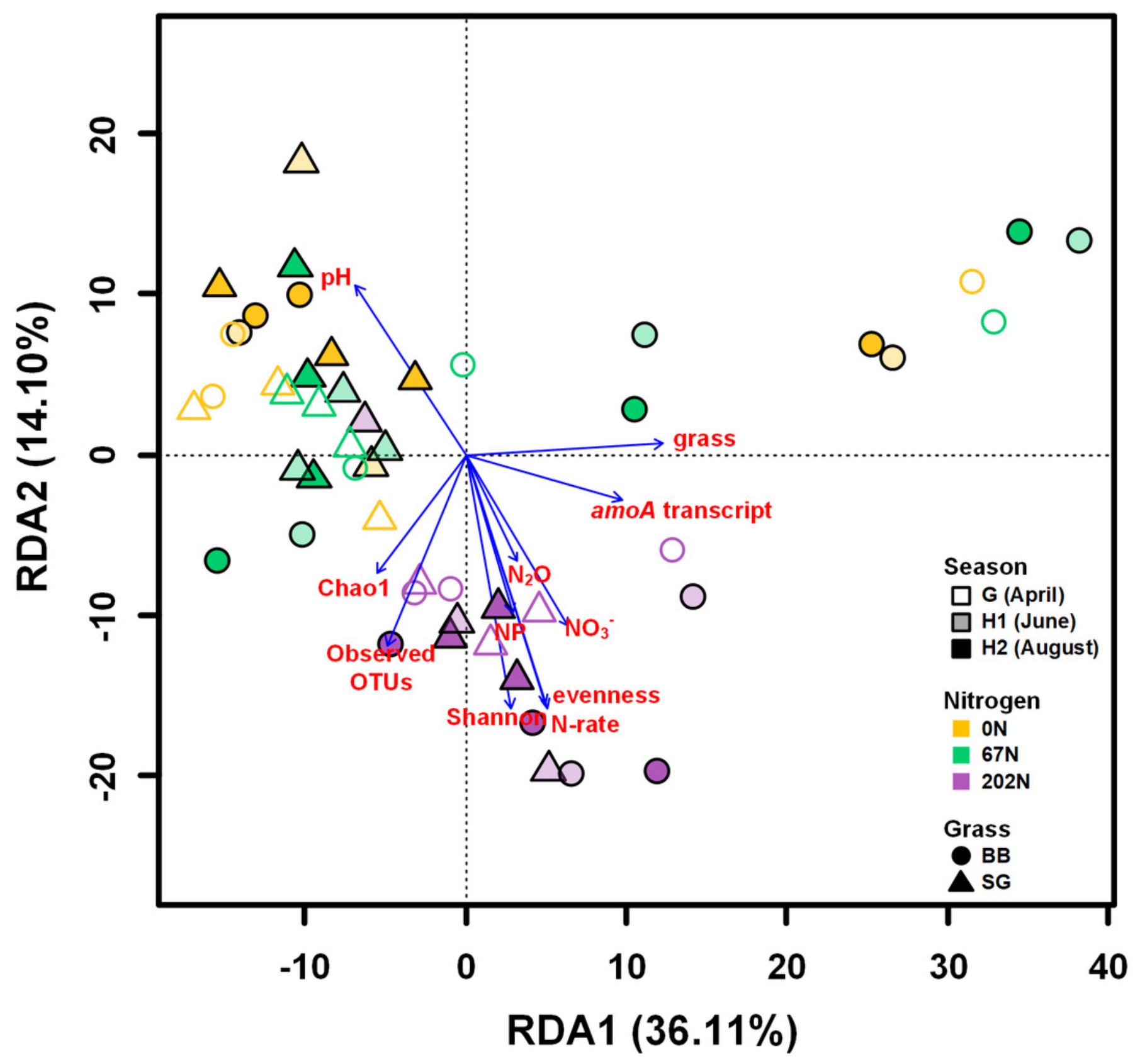




\section{Table 1 (on next page)}

Results of mixed model ANOVA (based on GLIMMIX procedure in SAS) testing effects of sampling season, nitrogen fertilization and grass species on soil properties and amoA gene and transcript abundances.

F-values are reported. 
1 Table 1. Results of mixed model ANOVA (based on GLIMMIX procedure in SAS) testing effects of sampling season, nitrogen

2 fertilization and grass species on soil properties and $a m o A$ gene and transcript abundances. F-values are reported.

\begin{tabular}{|c|c|c|c|c|c|c|c|}
\hline Effect & Season (S) & Nitrogen $(\mathrm{N})$ & Grass (G) & $\mathrm{N} \times \mathrm{G}$ & $\mathrm{S} \times \mathrm{N}$ & $\mathrm{S} \times \mathrm{G}$ & $\mathrm{S} \times \mathrm{N} \times \mathrm{G}$ \\
\hline $\mathrm{pH}$ & 3.26 & $11.70 * * *$ & $11.53 * *$ & 0.06 & 0.59 & 1.99 & 0.13 \\
\hline $\mathrm{SWC}^{\dagger}$ & $388.39 * * *$ & 0.31 & 0.01 & $3.75^{*}$ & 0.89 & 0.35 & 0.57 \\
\hline $\mathrm{NH}_{4}^{+}-\mathrm{N}$ & $23.06 * * *$ & 0.01 & 0.04 & 1.09 & $3.40^{*}$ & 3.05 & 1.35 \\
\hline $\mathrm{NO}_{3}^{-}-\mathrm{N}$ & $9.00 * * *$ & $31.14 * * *$ & 1.95 & 0.17 & 1.41 & $5.42 * *$ & 1.61 \\
\hline DOC & $57.99 * * *$ & $7.71 * *$ & 0.2 & 2.62 & 1.48 & 0.98 & 0.21 \\
\hline $\mathrm{DON}$ & $6.10 * *$ & 1.2 & 1.91 & 1.06 & 1.64 & 0.83 & 1.13 \\
\hline TOC & 0.43 & 0.88 & 0.11 & 1.13 & 1.58 & 1.22 & 0.84 \\
\hline $\mathrm{TN}$ & 1.11 & 2.44 & 0.82 & 0.08 & 1.79 & 1.52 & 0.53 \\
\hline $\mathrm{C}: \mathrm{N}$ ratio & 0.98 & 2.15 & 2.01 & $4.35^{*}$ & 0.24 & 0.24 & 0.26 \\
\hline $\mathrm{N}_{2} \mathrm{O}-\mathrm{N}$ & $12.46 * * *$ & $5.94 * *$ & 2.25 & 2.38 & $5.36^{* *}$ & 1.78 & $3.00 *$ \\
\hline Nitrification potential & $31.13 * * *$ & $21.85 * * *$ & $10.44 * *$ & 0.28 & $2.72 *$ & 0.13 & 0.3 \\
\hline amo $A$ genes & $91.22 * * *$ & $15.72 * * *$ & $8.33 * *$ & 1.13 & 0.34 & 1.56 & 0.25 \\
\hline$a m o A$ transcript & $17.20 * * *$ & $8.30 * *$ & 0.67 & 1.44 & $3.33^{*}$ & 0.92 & 0.48 \\
\hline
\end{tabular}

3 Significance level: * $0.01<p$-value $\leq 0.05 ; * * 0.001<p$-value $\leq 0.01 ; * * * p$-value $\leq 0.001$.

4 †SWC, soil water content; DOC, dissolved organic carbon; DON, dissolved organic nitrogen, TOC, total organic carbon; TN, total 5 nitrogen. 


\section{Table 2 (on next page)}

Results of PERMANOVA examining the importance of the effects of season, $\mathrm{N}$ application rate, and grass species on the variation in ammonia-oxidizing bacterial community composition. 
1 Table 2. Results of PERMANOVA examining the importance of the effects of season, $\mathrm{N}$

2 application rate, and grass species on the variation in ammonia-oxidizing bacterial community 3 composition.

\begin{tabular}{ccccc}
\hline Factor & Df & F.Model & $R^{2}$ & $p$-value $^{\dagger}$ \\
\hline Season & 2 & 1.184 & 0.024 & 0.304 \\
Nitrogen & 2 & 24.706 & 0.504 & $\mathbf{0 . 0 0 1}$ \\
Grass & 1 & 4.101 & 0.042 & $\mathbf{0 . 0 2 1}$ \\
Season $\times$ Nitrogen & 4 & 0.425 & 0.017 & 0.931 \\
Season $\times$ Grass & 2 & 0.789 & 0.016 & 0.534 \\
Nitrogen $\times$ Grass & 2 & 1.640 & 0.033 & 0.164 \\
Season $\times$ Nitrogen $\times$ Grass & 4 & 0.661 & 0.027 & 0.741 \\
Residuals & 33 & & 0.336 &
\end{tabular}

4 †old values indicate $p$-value $\leq 0.05$. 